\title{
Initial decomposition of floating leaf blades of waterlilies: causes, damage types and impacts
}

\author{
Peter F Klok ${ }^{1,2}$, Gerard van der Velde ${ }^{\text {Corresp. } 1,3}$ \\ 1 Department of Animal Ecology and Physiology, Institute for Water and Wetland Research, Radboud University, Nijmegen, Netherlands \\ 2 Department of Particle Physics, Institute for Mathematics, Astrophysics and Particle Physics, Radboud University, Nijmegen, Netherlands \\ 3 Naturalis Biodiversity Center, Leiden, Netherlands \\ Corresponding Author: Gerard van der Velde \\ Email address: g.vandervelde@science.ru.nl
}

The initial decomposition of large floating-leaved macrophytes, such as waterlilies, can be studied by following changes in leaf damage and area loss of leaf blades tagged in their natural environment. This approach was taken in the present study to examine the initial decomposition patterns of floating leaf blades of Nuphar lutea (L.) Sm., Nymphaea alba L. and Nymphaea candida C. Presl at three freshwater sites differing in nutrient status, alkalinity and $\mathrm{pH}$. Floating leaf blades of the three plant species were tagged and numbered within established replicate plots and the leaf length, percentages and types of damage and decay of all tagged leaves were recorded weekly during the growing season. Microbial decay, infection by phytopathogenic fungi (Colletotrichum nymphaeae) and oomycetes (Pythium sp.), consumption by pond snails, and mechanical factors were the most important causes of leaf damage. Several types of succession comprising different causes of damage were distinguished during the season. For example, young floating leaves are affected by more or less specialized invertebrate species consuming leaf tissue, followed by non-specialized invertebrate species feeding on the damaged floating leaves. In the two investigated hardwater lakes the seasonal patterns of initial decomposition differed between Nymphaea and Nuphar. 
1 Initial decomposition of floating leaf blades of waterlilies: causes, damage types and

2 impacts

3

4 Peter F. Klok and Gerard van der Velde

5

$6 \quad$ P. F. Klok $\cdot$ G. van der Velde $(\bowtie)$

7 Department of Animal Ecology and Physiology, Institute for Water and Wetland

8 Research, Radboud University, Nijmegen, The Netherlands

9 e-mail: g.vandervelde@science.ru.nl

11 P. F. Klok

12 Department of Particle Physics, Institute for Mathematics, Astrophysics and Particle

13 Physics, Radboud University, Nijmegen, The Netherlands

14

15 G. van der Velde

16 Naturalis Biodiversity Center, Leiden, The Netherlands 
18 Abstract

19 The initial decomposition of large floating-leaved macrophytes, such as waterlilies, can be

20 studied by following changes in leaf damage and area loss of leaf blades tagged in their natural

21 environment. This approach was taken in the present study to examine the initial decomposition

22 patterns of floating leaf blades of Nuphar lutea (L.) Sm., Nymphaea alba L. and Nymphaea

23 candida C. Presl at three freshwater sites differing in nutrient status, alkalinity and $\mathrm{pH}$. Floating

24 leaf blades of the three plant species were tagged and numbered within established replicate plots

25 and the leaf length, percentages and types of damage and decay of all tagged leaves were

26 recorded weekly during the growing season. Microbial decay, infection by phytopathogenic

27 fungi (Colletotrichum nymphaeae) and oomycetes (Pythium sp.), consumption by pond snails,

28 and mechanical factors were the most important causes of leaf damage. Several types of

29 succession comprising different causes of damage were distinguished during the season. For

30 example, young floating leaves are affected by more or less specialized invertebrate species

31 consuming leaf tissue, followed by non-specialized invertebrate species feeding on the damaged

32 floating leaves. In the two investigated hardwater lakes the seasonal patterns of initial

33 decomposition differed between Nymphaea and Nuphar. 


\section{Introduction}

39 The decomposition of leaf blades of floating-leaved macrophytes commences when the

40 leaves are still connected to the parent plant. The usual approach to study this process is to

41 place detached or harvested plant material in litter bags (Brock et al., 1982; Wieder \&

42 Lang, 1982; Taketani et al., 2018). Much less attention has been paid to the initial

43 decomposition of aquatic macrophytes before detachment or harvesting. Decomposition in

44 these natural conditions involves a complex set of interacting processes, which can be

45 classified into internal (physiological) and external (abiotic or biotic) processes (van der

46 Velde et al., 1982). Often, various stages and causes of decomposition occur on one plant

47 or even on a single leaf.

48 During initial decomposition macrophyte tissue can be used by herbivores and by

49 phytopathogenic and saprotrophic microorganisms. Before death, the plant tissue senesces

50 and further decomposition and disintegration is initiated by weak pathogens and

51 facultative herbivores, leading to the production of debris and fecal pellets. The chemical

52 composition of plant tissue also changes during senescence due to the hydrolysis of

53 macromolecules, which can weaken tissue structure, the resorption of nutrients like $\mathrm{N}$ and

$54 \mathrm{P}$ as well as carbon compounds such as starch, and the loss of secondary compounds. 
55 Furthermore, leaves are colonized by microorganisms, which make the tissue more

56 attractive for detritivorous macroinvertebrates (Rogers \& Breen, 1983).

57 The phases of initial decomposition can be studied well in floating leaf blades

58 (laminae) of large-leaved plants such as waterlilies (Nymphaeaceae) which exist for a

59 relatively long time, on average 38-48 days, and whose turnover is low $\left(\mathrm{P} / \mathrm{B}_{\max } 1.35-2.25\right.$

$60 \mathrm{yr}^{-1}$ ) (Klok \& van der Velde, 2017). Waterlilies occur worldwide (Conard, 1905;

61 Wiersema, 1987; Padgett, 2007) and in many types of water bodies differing in physico-

62 chemical conditions (van der Velde, Custers \& de Lyon, 1986). Waterlilies typically

63 occupy a fixed position in the plant zonation in the littoral zone of lakes between emergent

64 and submerged macrophytes. The nymphaeid growth form combines floating leaves with

65 rooting in the sediment (Luther, 1983; Den Hartog \& van der Velde, 1988). In addition,

66 waterlilies produce thin underwater leaves and aerial leaves when crowding occurs at the

67 water surface or water levels are lowered (Glück, 1924; van der Velde, 1980).

69 the water surface where they are attacked by various organisms, although young leaves

70 can already be attacked under water before they unroll (Lammens \& van der Velde, 1978;

71 van der Velde et al., 1982; van der Velde \& van der Heijden, 1985; Martínez \&

72 Franceschini, 2018). Responses of waterlilies to attacks include replacing old leaves by

73 new ones, shifting from floating leaves to underwater leaves (Kouki, 1993), producing 
74 hydrophobic epicuticular wax layers (Riederer \& Müller, 2006; Aragón, Reina-Pinto \&

75 Serrano, 2017) (Fig. 1), spines (Zhang \& Yao, 2018), sclereids containing calcium oxalate

76 crystals (Brock \& van der Velde, 1983; Franceschi \& Nakata, 2005), tough tissue (Kok et

77 al., 1992; Mueller \& Dearing, 1994), and plant secondary metabolites such as alkaloids

78 (Hutchinson, 1975) and phenolics (Kok et al., 1992; Vergeer \& van der Velde, 1997;

79 Smolders et al., 2000; Martínez \& Franceschini, 2018). This means that only specific

80 species are able to attack the fresh plant tissue. These species are more or less specialized

81 and often restricted to particular plant taxa. Other species colonize the leaves at later

82 stages after the defense system has been weakened (Kok et al., 1992). Damage of leaves

83 can induce the leaching of soluble carbohydrates such as oligosaccharides and starch,

84 proteinaceous and phenolic compounds, some of which can be rapidly metabolized by

85 microorganisms (Brock, Boon \& Paffen, 1985). Partially decayed floating leaves sink to

86 the bottom, where they provide a resource fuelling detritus-based benthic food webs and

87 continue being decomposed (Brock, 1985; van der Velde \& van der Heijden, 1985; Kok \&

88 van der Velde, 1991; Kok et al., 1992; Kok, 1993). The present study summarizes causes and patterns of initial decomposition of

90 floating leaves of three species of waterlilies in three water bodies differing in $\mathrm{pH}$,

91 alkalinity, nutrient levels and surrounding land use. Data from previous studies were

92 compiled to answer three questions: 1) What are the causes and patterns of initial 
93 decomposition of floating leaves? 2) What is the impact of each cause? 3) How does

94 initial decomposition progress during the season?

95

\section{Materials and Methods}

\section{Sites}

98 Field research took place in dense, nearly mono-specific stands of waterlilies in three

99 different water bodies located in The Netherlands: Haarsteegse Wiel (HW), Oude Waal

100 (OW) and Voorste Goorven (VG) (Table 1). Three plots were laid out in stands of Nuphar

101 lutea (L.) Sm. (HW and OW in 1977; VG in 1988), two plots in stands of Nymphaea alba

102 L. (OW in 1977; VG in 1988) and one plot in a stand of Nymphaea candida C. Presl in J.

103 et C. Presl (HW in 1977). The plots were accessed with a small zodiac, which was

104 navigated by gently paddling. Otherwise no boating or navigation occurred in the water

105 bodies, which prevented damage of the plants by propellers.

106 Haarsteegse Wiel, located in the Province of Noord-Brabant, originates from two

107 connected ponds created by dike bursts along the River Meuse. The now isolated water

108 body is eutrophic and has a relatively low alkalinity. The water level fluctuates, depending

109 on precipitation, groundwater seepage and evaporation. Stratification of the water column

110 occurs during summer. The lake bottom consists of sand and an organic layer with 
111 increasing thickness towards the littoral zone. The waterlily beds are situated in the wind-

112 sheltered part of the lake.

113 Oude Waal in the Province of Gelderland is a highly eutrophic oxbow lake in the

114 forelands of the River Waal. Depth during the growing season is shallow, except for three

115 connected breakthrough ponds. The water level is dependent on precipitation,

116 groundwater seepage, overflow of the River Waal in winter or spring, which strongly

117 influences water chemistry and quality, and evaporation. The bottom consisting of clay

118 and sand is covered by an organic layer of varying thickness in the nymphaeid beds.

119 Finally, Voorste Goorven in the Province of Noord-Brabant is a shallow,

120 oligotrophic, isolated, culturally acidified moorland pond with very low alkalinity. It is

121 surrounded by forests stocking on poorly buffered sandy soils. The hydrology is mainly

122 dependent on precipitation, groundwater seepage and evaporation.

123

\section{Leaf area}

125 The potential and actual leaf areas were determined to quantify leaf area loss. The

126 potential area refers to the area of the intact leaf. The actual area was defined as the

127 potential area minus the area that was missing. The potential leaf area was calculated by

128 using a quadratic regression to relate it to leaf length (van der Velde \& Peelen-Bexkens,

129 1983; Klok \& van der Velde, 2017) (Table 2). Specifically, undamaged, fully green 
130 floating leaves randomly sampled outside the plots were taken to the laboratory where

131 both length and area were measured to establish relationships of the form:

$$
A(L) \quad=c_{i} L^{2}
$$

133 where:

$$
A(L) \quad=\text { potential leaf area at length } L\left(\mathrm{~cm}^{2}\right)
$$

$L \quad=$ leaf length from the leaf tip to a basal lobe tip (cm)

$c_{i} \quad=$ regression coefficient of species $i$

$i \quad=$ species (Nuphar lutea, Nymphaea alba, Nymphaea candida)

\section{Study design and data collection}

140 Six representative plots of $1 \mathrm{~m}^{2}$ were laid out in the center of mono-specific stands, each

141 containing one rhizome apex per plot. A non-destructive method was used to tag all

142 floating leaves individually within the plots (Klok \& van der Velde, 2017). Newly

143 unrolled leaves were tagged with uniquely numbered Rotex tape fixed around the petiole

144 just under the leaf blade. This enabled us to collect data during the full life-span of the

145 leaves. Each plot was bordered by a square perforated PVC tube frame, held

146 approximately $15 \mathrm{~cm}$ below the water surface by cork floaters and anchored to the bottom

147 by four bricks. This set-up does not affect the unrolling of floating leaves in the plots. All

148 leaves having their petioles within the frame were counted and measured. A leaf was 
149 considered present as long as, after partial degradation and disintegration, tissue of the

150 lamina was connected to the petiole in the case of $\mathrm{OW}$ and $\mathrm{HW}$. In VG a leaf was

151 considered 'gone' when it was completely brown, dead and submerged, or when it had

152 disappeared.

153 All leaves within the plots were inspected and measured at weekly intervals

154 during the growing season, typically from April until November. Site visits involved

155 tagging newly unrolled leaves, counting the number of leaves, measuring leaf length from

156 the leaf tip to one of the basal lobe tips and visually estimating different types of initial

157 decomposition expressed as percentage of the potential leaf area of each leaf. Leaves

158 showing several types of damage were harvested outside the plots to be photographed in

159 the laboratory.

160

\section{Results}

162 Leaves developed during 53 to $73 \%$ of the vegetation period of 135 to 199 days (Klok \&

163 van der Velde, 2017). Loss of leaf tissue tended to increase during the vegetation period

164 (Fig. 2; Table 3). In the hardwater lakes (OW and HW), leaf area loss by damage of

165 Nuphar lutea and Nymphaea alba was less than $20 \%$ of the total potential leaf area until

166 mid-September, but increased to more than $50 \%$ thereafter. Leaf area loss by damage of

167 Nymphaea candida (HW) was less than $10 \%$ of the potential area in the beginning and 
168 increased to almost $20 \%$ in September-October. In the acidic moorland pond (VG) leaf

169 area loss was minimal as these leaves did not disintegrate.

170

171 Causes and impacts of initial decomposition

172 The causes of damage classified in the present study are senescence, frost, hailstones,

173 dehydration, mechanical damage, bird scratches, feeding waterfowl (Fulica atra L. and

174 Gallinula chloropus L., Rallidae), pond snails (Lymnaea sp., Lymnaeidae, Gastropoda),

175 water-lily reed beetle (Donacia crassipes F., Chrysomelidae, Coleoptera), adults and

176 larvae of the water-lily leaf beetle (Galerucella nymphaeae L., Chrysomelidae,

177 Coleoptera), a weevil (Bagous rotundicollis Bohemann, Curculionidae, Coleoptera),

178 larvae of the aquatic moth brown china mark (Elophila nymphaeata (L.), Crambidae,

179 Lepidoptera), larvae of a dung fly (Hydromyza livens (Fabricius), Scathophagidae,

180 Diptera), chironomid larvae (Chironomidae, Diptera), including Endochironomus spp. and

181 Tribelos intextus (Walker), a phytopathogenic fungus (Colletotrichum nymphaeae (Pass.)

182 Aa) and an oomycete (Pythium sp.), and finally microbial decay (Fig. 3, Table 4). In some

183 cases, specific causes could not be identified.

184 Senescence. Senescence is visible by the change in leaf colour from green to yellow,

185 indicating that chlorophyll is degraded. The extent of yellow areas reached its maximum

186 towards the end of the growing season. In October the percentage of affected leaves was 
$187100 \%$; however, the yellow surface area was generally around $10 \%$ and loss of green

188 photosynthetic leaf tissue ranged between 10 and $20 \%$ of the total leaf loss. The extent of

189 leaf area turned yellow decreased over time, since brown leaf areas leading to microbial

190 decay became increasingly dominant (Fig. 4; Table 4).

191 Frost. Frost in early spring can damage the tips of young leaves sticking out of the water.

192 As a result, such leaves can lose up to one third of their area (Fig. 5). However, the effect

193 on the total leaf surface area was less than $5 \%$.

194 Hailstones. Occasional hailstone showers damage the floating leaves by penetrating the

195 leaf and leaving typical Y-shaped scars (Fig. 6). Leaf area damaged by hail was minimal.

196 Dehydration. High winds often lift floating leaves above the water surface and may flip

197 them over. Subsequently, those leaves are exposed to air, particularly the leaf margins,

198 leading to leaf desiccation (Fig. 7). The effect of desiccation stress on leaf surface area

199 was generally less than $5 \%$.

200 Mechanical damage. This type of damage is caused by wind and wave action resulting in

201 cracks in the leaf tissue or lost leaves when the petiole breaks (Fig. 7). Lost leaves were

202 ascribed to unknown causes. For Nuphar lutea at HW, Nymphaea alba at OW and

203 Nymphaea candida at HW, the percentage of leaves affected over the whole vegetation

204 period ranged from $60-80 \%$. Nuphar lutea at OW showed peaks of $90 \%$ in spring, $70 \%$ in 
205 autumn and $10 \%$ in summer. In contrast, Nuphar lutea at VG and Nymphaea alba at VG

206 showed no mechanical damage.

207 Bird scratches. Scratches are often caused by the claws of birds, mostly coots (Fulica

208 atra) but also the common moorhen (Gallinula chloropus), as they walk or run over the

209 leaves (Fig. 8). In general, the scratches are straight and affect only the epidermis of the

210 leaf, but angle-shaped cuts due to claws penetrating the leaf tissue also occur. The affected

211 leaf surface area was low, generally below 5\%, although a high percentage of leaves was

212 affected, sometimes up to $100 \%$ for all plots at HW and OW. In contrast, the plots at VG

213 showed no scratches.

214 Consumption by coots. Consumption of leaf tissue by coots can be recognized by

215 missing parts in the form of triangular areas at the edge of leaves. Sometimes major parts

216 of leaves are consumed. Generally, prints of the beak are visible around the consumed

217 areas (Fig. 9). Nevertheless, the overall effect on total leaf surface area was minimal. The

218 plots at VG showed no damage by coot consumption.

219 Consumption by pond snails. A major cause of damage on fresh leaf tissue is caused

220 mainly by Lymnaea stagnalis L., to a lesser extent also by other lymnaeids. Pond snails

221 consume folded leaves still under water. Rows of holes can then be seen in the unrolled

222 leaf blades, large near the edge and smaller towards the center of the leaf (Fig. 10).

223 Lymnaeid and other freshwater pulmonate snails show a preference for decaying leaf 
224 material, such as areas infected by fungi. Damage by snails was generally an important

225 cause of damage during the whole period for both Nuphar lutea and Nymphaea alba,

226 contributing up to $20 \%$ to the total leaf area loss in HW.

227 Consumption by water-lily reed beetles. Both Nuphar and Nymphaea spp. are host

228 plants of the water-lily reed beetle Donacia crassipes. The adult beetles live on the upper

229 side of floating leaves where they feed on leaf tissue (upper epidermis, parenchyma and

230 lower epidermis). The leaf areas removed as a result of tissue consumption by these

231 beetles are round to oval. Eggs are deposited in two or three rows on the leaf underside.

232 To this end, the beetle gnaws a round or oval hole in the leaf, then sticks its abdomen

233 through the hole to reach the leaf underside and oviposit (Fig. 11). The percentage of leaf

234 area damaged by reed beetles was minimal.

235 Consumption by water-lily leaf beetles. The water-lily leaf beetle (Galerucella

236 nymphaeae) completes its full life cycle on the upper surface of floating leaves. Both adult

237 beetles and larvae feed on the upper epidermis and palisade and sponge parenchyma. The

238 larvae create irregular trenches on the surface, leaving the lower epidermis of the leaf

239 intact and depositing their faeces in the trenches. The resulting pattern of leaf tissue

240 damage is easily recognized. The adult beetles consume smaller areas (Fig. 12). Damage

241 was only found in Nymphaea alba at VG, where leaves started to be affected in mid-June, 
242 rising to $30-40 \%$ between August and October and reaching a sharp peak of $60 \%$ in mid-

243 October. The percentage of lost leaf area was minimal.

244 Consumption by weevils. The adults of Bagous rotundicollis scrape off areas of leaf

245 tissue (ca. $1 \mathrm{~cm}$ diameter) from the underside of floating leaves near the margin. Only the

246 lower epidermis and sponge parenchyma are consumed, whereas the palisade parenchyma

247 and upper epidermis remain intact (Fig. 13). Damage by weevils was found only in

248 Nymphaea alba at VG, with up to $30 \%$ of these leaves being affected. Leaf area loss was

249 minimal.

250 Consumption and damage by the brown china mark. The caterpillar of the aquatic

251 moth Elophila nymphaeata damages floating leaves in two ways, by leaf tissue

252 consumption and by cutting out oval leaf patches that they can attach to the underside of a

253 floating leaf to make a shelter. They can also spin two patches together to construct a

254 floating shelter (Fig. 14). The effect of these activities on leaf surface area was low, at most 5\%. Nymphaea candida at HW, Nuphar lutea at VG and Nymphaea alba at VG were

256 not damaged by the moth.

257 Mining by a dung fly. Larvae of the dung fly Hydromyza livens only occurred in Nuphar

258 leaves, where they mine and consume leaf tissue. Eggs are laid at the underside of the

259 leaves. For that purpose the fly goes underwater, following the dichotomous veins on the

260 underside of the leaves till it reaches the midrib to lay an egg. The newly hatched larvae 
261 immediately start to mine the leaf tissue. The mine track has a characteristic shape as the

262 larvae first move from the midrib towards the margins of the leaf, then turn to continue

263 mining in parallel to the leaf margin, then turn again towards the midrib and mine further

264 into the petiole where they pupate. This creates a breaking point where the leaf blade can

265 detach and float away (Fig. 15). Overall, the effect of dung flies mining the leaves was

266 less than $8 \%$.

267 Mining by chironomids. Larvae of some Chironomidae mine their way through the leaf

268 tissue by consuming particular tissue layers while leaving the upper and lower epidermis

269 unaffected for protection. Typical damage on Nuphar leaves is caused by larvae of

270 Tribelos intextus. These larvae mine leaves still folded underwater, resulting in rows of

271 small holes that become visible when the floating leaves unroll at the water surface (Fig.

272 16). Also observed at the study sites were larvae of Cricotopus trifasciatus (Meigen) (Fig.

273 17), which makes an open mine by removing the upper epidermis while leaving the lower

274 epidermis intact. The species was observed in OW to cause some damage at the leaf 275 margins of Nuphar lutea in the neighbourhood of Nymphoides peltata (Gmel.) O. Kuntze,

276 its main food plant. Overall, however, the impact of these chironomid species on floating

277 leaves was minimal.

278 Mining by Endochironomus spp. Larvae of these midges mine in floating leaves. The

279 mines could clearly be distinguished from those of other Chironomidae described above,

280 since they appear on the upper side of the floating leaves as straight dark stripes (Fig. 18).

281 The total effect on the decomposition of floating leaves was minimal. 
282 Infection by phytopathogens. The leaves of Nuphar lutea were infected by the oomycete

283 Pythium "type F" (Fig. 19) and the leaves of Nymphaea alba and Nymphaea candida by

284 the fungus Colletotrichum nymphaeae, the causative agent of leaf spot disease (Fig. 20).

285 The percentage of damaged surface area was about $15 \%$ for Pythium and up to $55 \%$ for

286 Colletotrichum.

287 Microbial decay. The resistance of a leaf to microbial infection quickly disappears during

288 senescence, facilitating microbial decay (Fig. 4) as indicated by a change in leaf colour

289 from yellow to brown and the softening of leaf tissue by maceration. The affected surface

290 area rose to $15-25 \%$, with an exceptional extent of $60 \%$ reached in Nymphaea candida at

291 HW at the very end of the growing season.

292 Unknown causes. Missing leaves or parts thereof can result from various types of

293 damage, including animal consumption and mechanical damage. Missing leaf material

294 where the cause of loss could not be determined was registered under unknown causes.

295 These causes include leaves disconnected from their petioles and scattered by wind and

296 wave action, occasionally accounting for up to $60 \%$ of lost area for Nuphar lutea at HW,

297 Nymphaea alba at OW and Nymphaea candida at HW. However, such losses were rare for

298 Nuphar lutea at OW and VG and Nymphaea alba at VG.

300 Discussion 
301 Senescence. Newly unrolled leaf blades of waterlilies are fully green and hydrophobic due

302 to a thick epicuticular wax layer. This waxy layer gradually erodes during senescence and

303 as cellulolytic and other bacteria and fungi colonize the leaf tissue (Howard-Williams,

304 Davies \& Cross, 1978; Robb et al., 1979; Rogers \& Breen, 1981; Barnabas, 1992).

305 Senescence starts shortly after the first leaves are fully grown and continues throughout

306 the growth period. During senescence, an orderly physiological process controlled by the

307 plant itself, the leaves turn from green to yellow, and ultimately to brown. Concomitant

308 microbial decay softens the leaves.

309 Infection by phytopathogens and microbial decay. In Nuphar both microbial decay and

310 infection by the phytopathogenic oomycete Pythium sp. "type F" were important from the

311 start of the season. In Nymphaea, infection by the phytopathogenic fungus Colletotrichum

312 nymphaeae also started early and increased in importance towards the end of the season.

313 In general, microbial decay and phytopathogenic infection gradually increased in

314 importance, whereas most other causes of damage diminished over time.

315 Weather conditions. Minor causes of leaf impairment occurring once during spring were

316 frost damage of the first newly unrolled leaves and hailstones. Hailstones hardly caused

317 leaf area loss. High solar radiation and air temperature dehydrated leaves that had been

318 flipped over, with the impact being high in HW and OW but not in the wind-sheltered VG.

319 Prolonged cloudy and wet weather imposes stress on waterlilies by weakening the defense 
320 of leaves due to reduced solar radiation, and thus promoting heavy infection and damage

321 by phytopathogens (van der Aa, 1978). One mechanism is that poor light conditions

322 reduce the content of phenolics with fungistatic properties in the leaf tissue (Vergeer \&

323 van der Velde, 1997), which turns mature leaves vulnerable to infection.

324 Damage by animals. Causes of damage by insects were similar for Nymphaea and

325 Nuphar with the exception of Hydromyza livens and Tribelos intextus, which appear to be

326 specific for Nuphar (Brock \& van der Velde, 1983; van der Velde \& Hiddink, 1987).

327 Some species such as Bagous rotundicollis (van der Velde, Kok \& van Vorstenbosch,

328 1989) and Donacia crassipes (Gaevskaya, 1969) exclusively feed on Nymphaeaceae.

329 Other species such as Galerucella nymphaeae and Elophila nymphaeae feed on both

330 floating-leaved and emergent macrophytes (Gaevskaya 1969; Lammens \& van der Velde,

331 1978; Pappers et al., 2001). Cricotopus trifasciatus primarily causes damage on leaves of

332 Nymphoides peltata (Lammens \& van der Velde, 1978) but was also observed to damage

333 nearby Nuphar lutea leaves (van der Velde \& Hiddink, 1987).

334 In VG, damage was mainly caused by phytophagous insects consuming floating leaf

335 tissue, particularly herbivorous beetles, fly larvae and mining chironomid larvae. Leaf

336 disintegration was hardly observed in the acidic VG, which was also the site most

337 sheltered against wind and wave action by a surrounding forest. Protection from wind and

338 wave action allowed the water-lily leaf beetle Galerucella nymphaeae to cause extensive 
339 damage, because wind blows them from the leaves and they float away as a result of wave

340 action. Although this species spares the lower epidermis of their tracks, the epidermis

341 becomes vulnerable to microbial attack and thus disappears at a later stage (Wesenberg-

342 Lund, 1943; Roweck, 1988). As observed in the present study, the minor leaf area loss by

343 the beetle and its larvae is succeeded by damage caused by fungi, oomycetes or bacteria

344 (Wallace \& O'Hop, 1985). The damaged areas characterized by regular margins made by

345 adult Galerucella nymphaeae are distinct from those made by adult Donacia crassipes

346 where the margins of damaged areas are rather irregular (Roweck, 1988). Galerucella

347 nymphaeae was absent in the two water bodies frequently exposed to strong wind.

348 Consumption by snails was restricted to the two hardwater lakes, since they require

349 calcium to build their shells. Snails at those sites prefer consuming microbially colonized,

350 decaying parts of the leaves (Kok, 1993).

351 Nymphaea candida (HW) showed an increase in scratches by bird claws towards the end

352 of June, which may have been due to young coots. High densities of waterfowl at HW and

353 OW are facilitated by the surrounding meadows where birds graze during winter.

354 pH and alkalinity. Decomposition of leaves was slowed down at the acidic site (VG).

355 Such water bodies are characterized by a very low alkalinity and high Al concentrations of

356 the water, as well as low $\mathrm{pH}$ (Leuven, van der Velde \& Kersten, 1992). A laboratory study

357 in chemostats with synthetic media showed that $\mathrm{pH}, \mathrm{Al}$ and $\mathrm{HCO}_{3}{ }^{-}$concentrations clearly 
358 influence the decomposition and chemical composition of leaf blades of floating-leaf

359 plants, with low $\mathrm{pH}$ and elevated $\mathrm{Al}$ concentrations inhibiting and high bicarbonate

360 concentrations (alkalinity) stimulating decomposition (Kok, Meesters \& Kempers, 1990).

$361 \mathrm{Al}$ is toxic to microorganisms and low $\mathrm{pH}$ slows down leaf disintegration by inhibiting

362 cell-wall degradation by microbial pectin-degrading exoenzymes and xylanase (Kok \&

363 van der Velde, 1991). At low $\mathrm{pH}$, tannins accumulate in the slowly decomposing leaf

364 material, microbial colonization is inhibited and maceration of the leaf tissue is reduced,

365 resulting in a low-quality food resource for detritivores (Kok et al., 1992). The occurrence

366 of detritivores is also inhibited by high $\mathrm{Al}$ concentrations and low $\mathrm{pH}$ (Kok \& van der

367 Velde, 1994). Finally, fungal degradation of major groups of structural carbohydrates is

368 inhibited by low pH (Kok, Haverkamp \& van der Aa, 1992).

369 Harvested fresh and decaying leaf blades of Nymphaea alba placed in litter bags in

370 the field and in the laboratory showed lower leaf area loss under acidic conditions in a

371 moorland pond (VG) than in a eutrophic, hardwater oxbow lake (OW), and results under

372 laboratory conditions mimicking differences in water chemistry were similar (Brock,

373 Boon \& Paffen, 1985). Depending on water chemistry, mass loss was pronounced and

374 organic matter chemical composition changed rapidly during the first 10-30 days,

375 followed by an accumulation of structural plant polymers such as cellulose, hemicellulose 
376 and lignin. The disappearance of those fractions was dependent on the water quality of the

377 water body (Brock, Boon \& Paffen, 1985).

378 In conclusion, the present study shows that the decomposition pattern of Nuphar lutea was

379 similar in the two hardwater lakes, and differed from those of Nymphaea alba and $N$.

380 candida. In the acidic VG, the effect of leaf damage on leaf area loss was minimal for both

381 Nuphar lutea and Nymphaea alba.

382

\section{Acknowledgements}

384 We thank M. Ankersmid, R. Kwak, R. de Mooij, H. Peeters, F. Verhoeven, V. Vintges

385 and C.J. Kok for collecting field data, R.P.W.M. Jacobs and H.A. van der Aa for

386 identifying oomycetes and fungi, respectively, W. Lemmens for help with data analysis,

387 W.J. Metzger for English language corrections, and the editor Mark Gessner, reviewer

388 Manuela Abelho and one anonymous reviewer for constructive comments that very much

389 improved the manuscript.

390

391 References

392

393 Aragón W, Reina-Pinto JJ, Serrano M. 2017. The intimate talk between plants and

394 microorganisms at the leaf surface. Journal of Experimental Botany 68(19): 5339-5350. 
396 Barnabas AD. 1992. Bacteria on and within leaf blade epidermal cells of the seagrass

397 Thalassodendron ciliatum (Forskk.) Den Hartog. Aquatic Botany 43: 257-266.

398

399 Brock TCM, Huijbregts CAM, van de Steeg-Huberts MJHA, Vlassak MA. 1982. In situ

400 studies on the breakdown of Nymphoides peltata (Gmel.) O. Kuntze (Menyanthaceae);

401 some methodological aspects of the litter bag technique. Hydrobiological Bulletin 16(1):

$402 \quad 35-49$.

403

404 Brock TCM, van der Velde G. 1983. An autecological study on Hydromyza livens

405 (Fabricius) (Diptera, Scatomyzidae), a fly associated with nymphaeid vegetation

406 dominated by Nuphar. Tijdschrift voor Entomologie 126(3): 59-90.

407

408 Brock TCM. 1985. Ecological studies on nymphaeid water plants. Thesis. Catholic

409 University Nijmegen, 205 pp.

410

411 Brock TCM, Boon JJ, Paffen BGP. 1985. The effects of the season and water chemistry on the

412 decomposition of Nymphaea alba L. - weight loss and pyrolysis mass spectrometry of the

413 particulate organic matter. Aquatic Botany 22 (3-4): 197-229. 
415 Conard HS. 1905. The Waterlilies. A monograph of the genus Nymphaea. The Carnegie

416 Institute of Washington, $279 \mathrm{pp}$.

418 Den Hartog C, van der Velde G. 1988. Structural aspects of aquatic plant communities. In:

419 Symoens JJ, ed. Vegetation of inland waters. Handbook of vegetation science 15: 113-

420 153. Kluwer Academic Publishers, Dordrecht.

421

422 Franceschi VR, Nakata PA. 2005. Calcium oxalate in plants: Formation and function.

423 Annual Review in Plant Biology 56: 41-47.

425 Gaevskaya NS. 1969. The role of higher aquatic plants in the nutrition of the animals of

426 fresh-water basins. Volume I, II and III. Published by National Lending Library for

427 Science and Technology, Boston Spa, Yorkshire, England, 629 pp.

428

429 Glück H. 1924. Biologische und morphologische Untersuchungen über Wasser- und

430 Sumpfgewächse. Vierter Teil: Untergetauchte und Schwimmblattflora. Verlag von Gustav

431 Fischer, Jena, 746 pp. 
433 Howard-Williams C, Davies BR, Cross RHM. 1978. The influence of periphyton on the

434 surface structure of a Potamogeton pectinatus L. leaf (an hypothesis). Aquatic Botany 5:

$435 \quad 87-91$.

436

437 Hutchinson GE. 1975. A treatise on limnology Vol. III-Limnological Botany. New York:

438 John Wiley \& Sons, 660 pp.

439

440 Klok PF, van der Velde G. 2017. Plant traits and environment: floating leaf blade

441 production and turnover of waterlilies. PeerJ 5:e3212; DOI 10.7717/peerj.3212.

442

443 Kok CJ, Meesters HWG, Kempers AJ. 1990. Decomposition rate, chemical composition

444 and nutrient recycling of Nymphaea alba $\mathrm{L}$. floating leaf blade detritus as influenced by

$445 \mathrm{pH}$, alkalinity and aluminium in laboratory experiments. Aquatic Botany 37: 215-227.

446

447 Kok CJ, van der Velde G, Landsbergen KM. 1990. Production, nutrient dynamics and

448 initial decomposition of floating leaves of Nymphaea alba L., and Nuphar lutea (L.) Sm.

449 (Nymphaeaceae) in alkaline and acid waters. Biogeochemistry 11: 235-250.

450 
451 Kok CJ, van der Velde G. 1991. The influence of selected water quality parameters on the

452 decay and exoenzymatic activity of detritus of floating leaf blades of Nymphaea alba $\mathrm{L}$. in

453 laboratory experiments. Oecologia 88: 311-316.

454

455 Kok CJ, Haverkamp W, van der Aa HA. 1992. Influence of $\mathrm{pH}$ on the growth and leaf

456 maceration ability of fungi involved in the decomposition of floating leaves of Nymphaea

457 alba in an acid water. Journal of General Microbiology 138: 103-108.

458

459 Kok CJ, Hof CHJ, Lenssen JPM, van der Velde G. 1992. The influence of pH on

460 concentrations of protein and phenolics and resource quality of decomposing floating leaf

461 material of Nymphaea alba L. (Nymphaeaceae) for the detritivore Asellus aquaticus (L.).

462 Oecologia 91: 229-234.

463

464 Kok CJ. 1993. Decomposition of floating leaves of Nymphaea alba L. under alkaline and

465 acid conditions. Doctoral Thesis, Catholic University Nijmegen, $121 \mathrm{pp}$.

466

467 Kok CJ, van der Velde G. 1994. Decomposition and macroinvertebrate colonization of

468 aquatic and terrestrial leaf material in an alkaline and an acid still water. Freshwater

469 Biology 31: 65-75. 
471 Kouki J. 1993. Herbivory modifies the production of different leaf types in the yellow

472 water-lily, Nuphar lutea (Nymphaeaceae). Functional Ecology 7: 21-26.

473

474 Lammens EHRR, van der Velde G. 1978. Observations on the decomposition of Nymp-

475 hoides peltata (Gmel.) O. Kuntze (Menyanthaceae) with special regard to the

476 leaves. Aquatic Botany 4: 331-346.

477

478 Leuven RSEW, van der Velde G, Kersten HLM. 1992. Interrelations between pH and other

479 physico-chemical factors. Archiv für Hydrobiologie 126: 27-51.

480

481 Luther H. 1983. On life forms, and above-ground and underground biomass of aquatic

482 macrophytes. Acta Botanica Fennica 123: 1-23.

483

484 Martínez FS, Franceschini C. 2018. Invertebrate herbivory on floating-leaf macrophytes at

485 the northeast of Argentina: should the damage be taken into account in estimations of plant 
486 biomass? Anais da Academia Brasileira de Ciências 90(1): 12 pp.

487 http://dx.doi.org/10.1590/0001-3765201820170415.

488

489 Mueller UG, Dearing MD. 1994. Predation and avoidance of tough leaves by aquatic

490 larvae of the moth Paraponyx rugosalis (Lepidoptera, Pyralidae). Ecological Entomology

491 19(2): 155-158.

492

493 Padgett DJ. 2007. A monograph of Nuphar (Nymphaeaceae). Rhodora 109 (937): 1-95.

494

495 Pappers SM, van Dommelen H, van der Velde G, Ouborg NJ. 2001. Differences in 496 morphology and reproduction traits of Galerucella nymphaeae from four host plant 497 species. Entomologia Experimentalis et Applicata 99: 183-191.

498

499 Riederer M, Müller C (eds). 2006. Biology of the plant cuticle. Annual Plant Reviews,

500 Vol. 23. Blackwell, Oxford, 438 pp.

501

502 Robb F, Davies BR, Cross R, Kenyon C, Howard-Williams C. 1979. Cellulolytic bacteria

503 as primary colonizers of Potamogeton pectinatus L. (Sago pond weed) from a brackish

504 south-temperate coastal lake. Microbial Ecology 5: 167-177. 
506 Rogers KH, Breen CM. 1981. Effects of periphyton on Potamogeton pectinatus L. leaves.

507 Microbial Ecology 7: 351-361.

508

509 Rogers KH, Breen CM. 1983. An investigation of macrophyte epiphyte and grazer

510 interactions. In: Wetzel, R.G. (ed.). Periphyton of freshwater ecosystems. Developments in

511 Hydrobiology 17: 217-226.

512

513 Roweck H. 1988. Ökologische Untersuchungen an Teichrosen. Archiv für Hydrobiologie

514 Monographische Beiträge Supplementband 81 (2/3): 103-358. Stuttgart: E.

515 Schweizerbart'sche Verlagbuchhandlung (Nägele u. Obermiller).

516

517 Smolders AJP, Vergeer LHT, van der Velde G, Roelofs JGM. 2000. Phenolic contents of

518 submerged, emergent and floating leaves of (semi-) aquatic macrophyte species. Why do

519 they differ? Oikos 91: 307-310. 
521 Taketani R, Moitinho MA, Mauchline TH, Melo IS. 2018. Co-occurrence patterns of litter

522 decomposing communities in mangroves indicate a robust community resistant to

523 disturbances. PeerJ 6: article number e5710.

524

525 van der Aa HA. 1978. A leaf spot disease of Nymphaea alba in the Netherlands.

526 Netherlands Journal of Plant Pathology 84: 109-115.

527

528

van der Velde G. 1980. Studies in nymphaeid-dominated systems with special emphasis

529

on those dominated by Nymphoides peltata (Gmel.) O. Kuntze (Menyanthaceae). Doctoral

530

Thesis, Catholic University Nijmegen, 163 pp.

531

532 van der Velde G, van der Heijden LA, van Grunsven PAJ, Bexkens PMM. 1982. Initial

533 decomposition of Nymphoides peltata (Gmel.) O. Kuntze (Menyanthaceae), as studied by

534 the leaf-marking method. Hydrobiological Bulletin 16 (1):51-60.

535

536 van der Velde G, Peelen-Bexkens PMM. 1983. Production and biomass of floating leaves

537 of three species of Nymphaeaceae in two Dutch waters. Proceedings of the International

538 Symposium on Aquatic Macrophytes, Nijmegen, The Netherlands, 18-23 September,

$5391983,230-235$. 
541 van der Velde G, van der Heijden LA. 1985. Initial decomposition of floating leaves of

542 Nymphoides peltata (Gmel.) O. Kuntze (Menyanthaceae) in relation to their age, with

543 special attention to the role of herbivores. Verhandlungen der Internationalen Vereinigung

544 für theoretische und angewandte Limnologie 22: 2937-2941.

545

546 van der Velde G, Custers CPC \& de Lyon MJH. 1986. The distribution of four nymphaeid

547 species in the Netherlands in relation to selected abiotic factors. Proceedings of the European

548 Weed Research Society/Association of Applied Biologists, 7th Symposium on Aquatic Weeds,

549 Loughborough, UK, 1986, 363-368.

550

551 van der Velde G, Hiddink R. 1987. Chironomidae mining in Nuphar lutea (L.) Sm.

552 (Nymphaeaceae). Entomologica Scandinavica Supplement 29: 255-264.

553

554 van der Velde G., Kok CJ, van Vorstenbosch HJWT. 1989. Bagous rotundicollis, new for

555 The Netherlands, feeding on waterlily leaves (Coleoptera: Curculionidae). Entomologische

556 Berichten, Amsterdam 49: 57-60. 
558 Vergeer LHT, van der Velde G. 1997. The phenolic content of daylight-exposed and

559 shaded floating leaves of water lilies (Nymphaeaceae) in relation to infection by fungi.

560 Oecologia 112: 481-484.

561

562 Wallace JB, O'Hop, J. 1985. Life on a fast pad - Waterlily leaf beetle impact on water

563 lilies. Ecology 66 (5): 1534-1544

564

565 Wesenberg-Lund C. 1943. Biologie der Süsswasserinsekten. Springer-Verlag, Berlin, 682

566 pp.

567

568 Wieder RK, Lang GE. 1982. A critique of the analytical methods used in examining

569 decomposition data obtained from litter bags. Ecology 63 (6): 1636-1642.

570

571 Wiersema JH. 1987. A monograph of Nymphaea subgenus Hydrocallis (Nymphaeaceae).

572 Systematic Botanical Monographs 16: 1-112.

573 
574 Zhang G, Yao R. 2018. The spinescent aquatic plants in the Yangtze Delta, East China.

575 Israel Journal of Plant Science $65 \quad$ (1-2): 9-16.

576 http://dx.doi.org/10.1080/07929978.2017.1279440.

577 


\section{Figure 1}

\section{Defense system.}

A newly enrolled floating leaf of Nymphaea alba showing the hydrophobic wax layer as indicated by water droplets.

*Note: Auto Gamma Correction was used for the image. This only affects the reviewing manuscript. See original source image if needed for review.

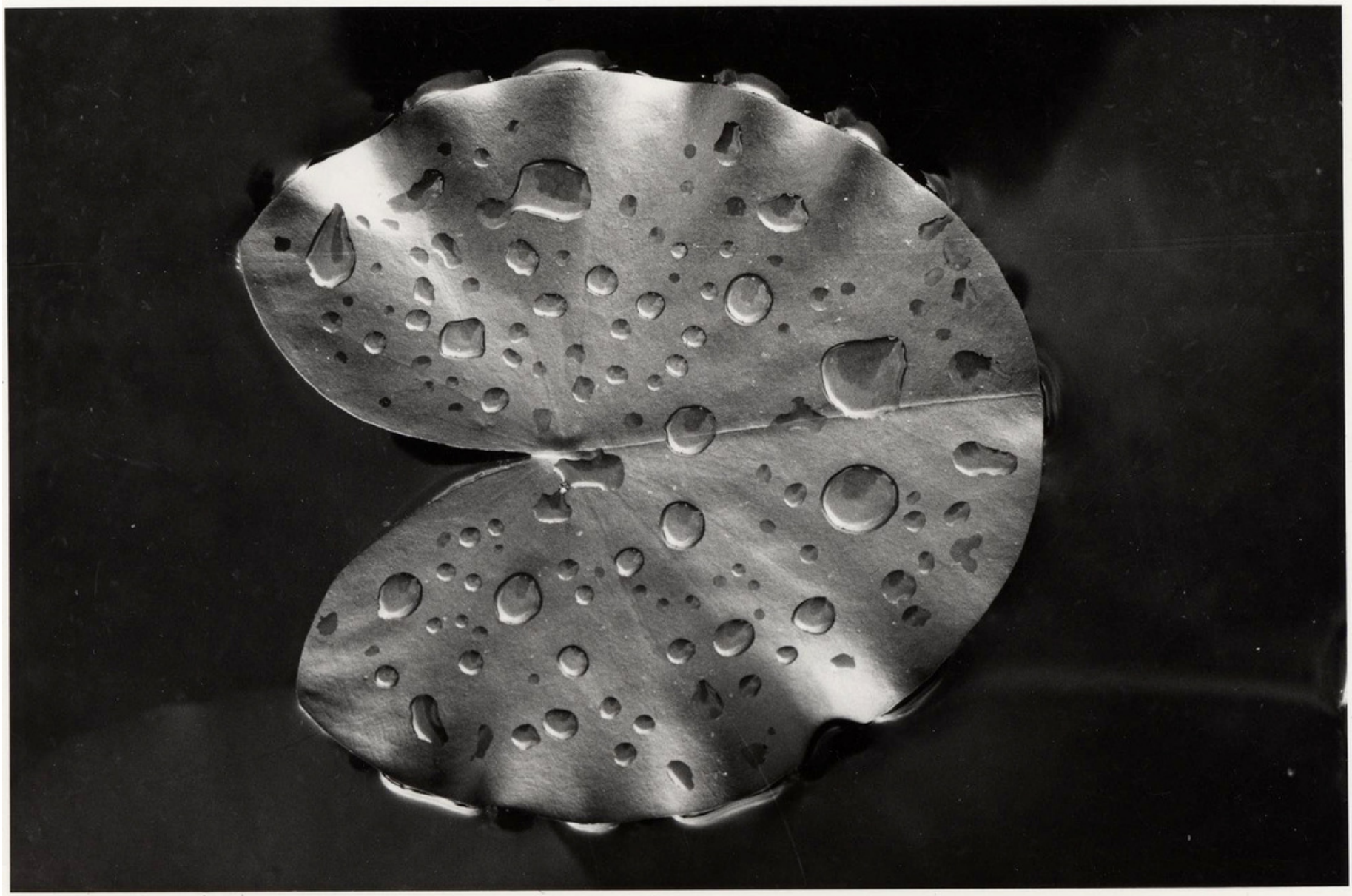


Figure 2

Photosynthetic leaf area loss by external causes in time per plot.

Seasonal changes in the loss of photosynthetic leaf area caused by external factors, shown as the difference between the actual surface (lower line) and the potential surface (upper line) in six field plots. (A) Nuphar lutea, HW, 1977, (B) Nuphar lutea, OW, 1977, (C) Nymphaea alba, OW, 1977, (D) Nymphaea candida, HW, 1977, (E) Nuphar lutea, VG, 1988, (F) Nymphaea alba, VG, 1988.
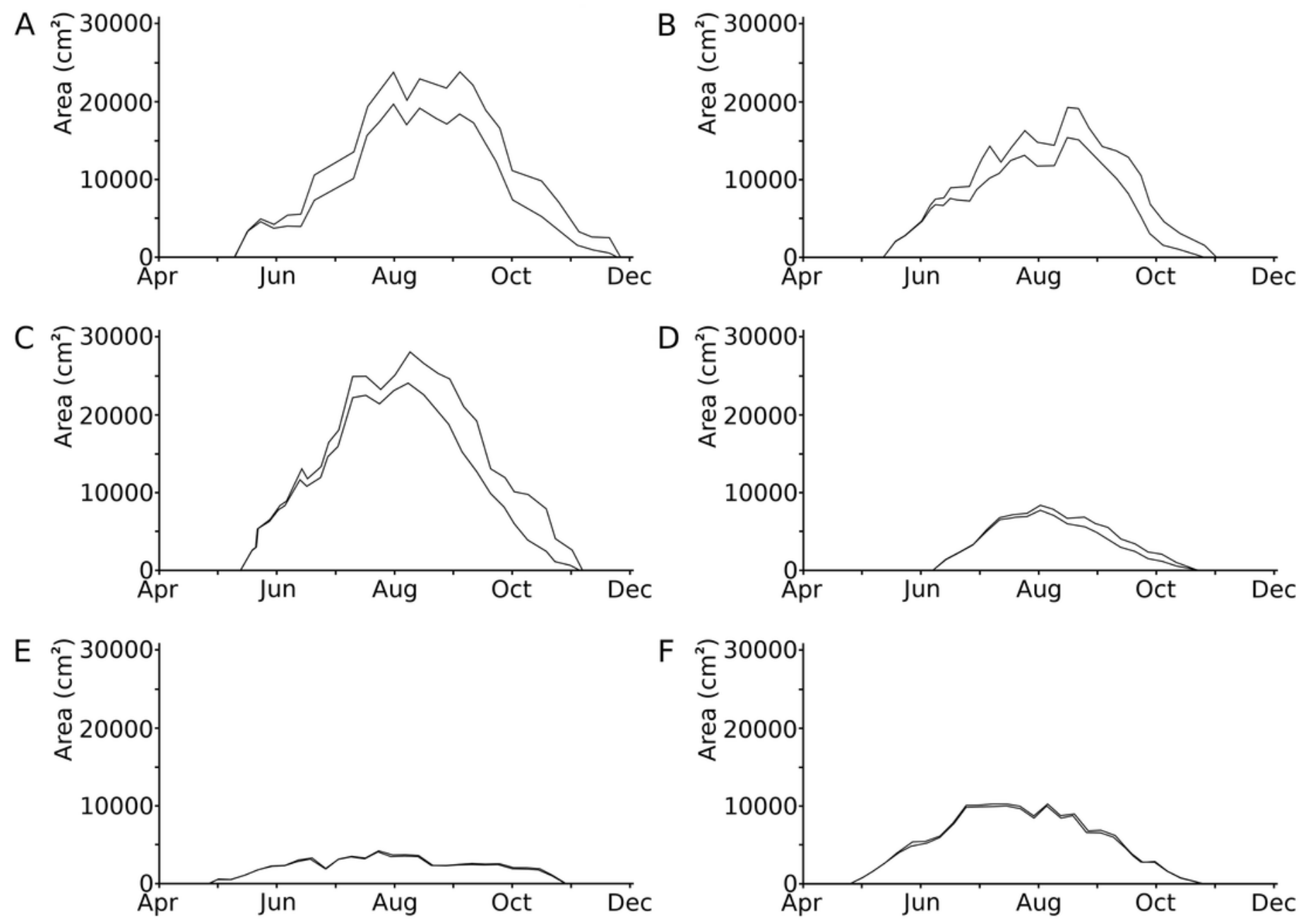


\section{Figure 3}

Relative contributions to leaf damage by external causes per plot in time.

Seasonal changes in the relative contributions to leaf damage by external causes in six field plots. (A) Nuphar lutea, HW, 1977, (B) Nuphar lutea, OW, 1977, (C) Nymphaea alba, OW, 1977, (D) Nymphaea candida, HW, 1977, (E) Nuphar lutea, VG, 1988, (F) Nymphaea alba, VG, 1988.

$1=$ Frost, 2 = Dehydration, $3=$ Mechanical damage, $4=$ Scratches, 5 = Damage by Elophila nymphaeata, 6 = Consumption by Fulica atra, $7=$ Consumption by snails, $8=$ Consumption by Donacia crassipes, $9=$ Consumption by Bagous rotundicollis, $10=$ Consumption by Galerucella nymphaeae, $11=$ Mining by Hydromyza livens, 12 = Mining by Chironomidae, 13 = Mining by Endochironomus, $14=$ Fungi, $15=$ Microbial decay, 16 = Unknown causes. 

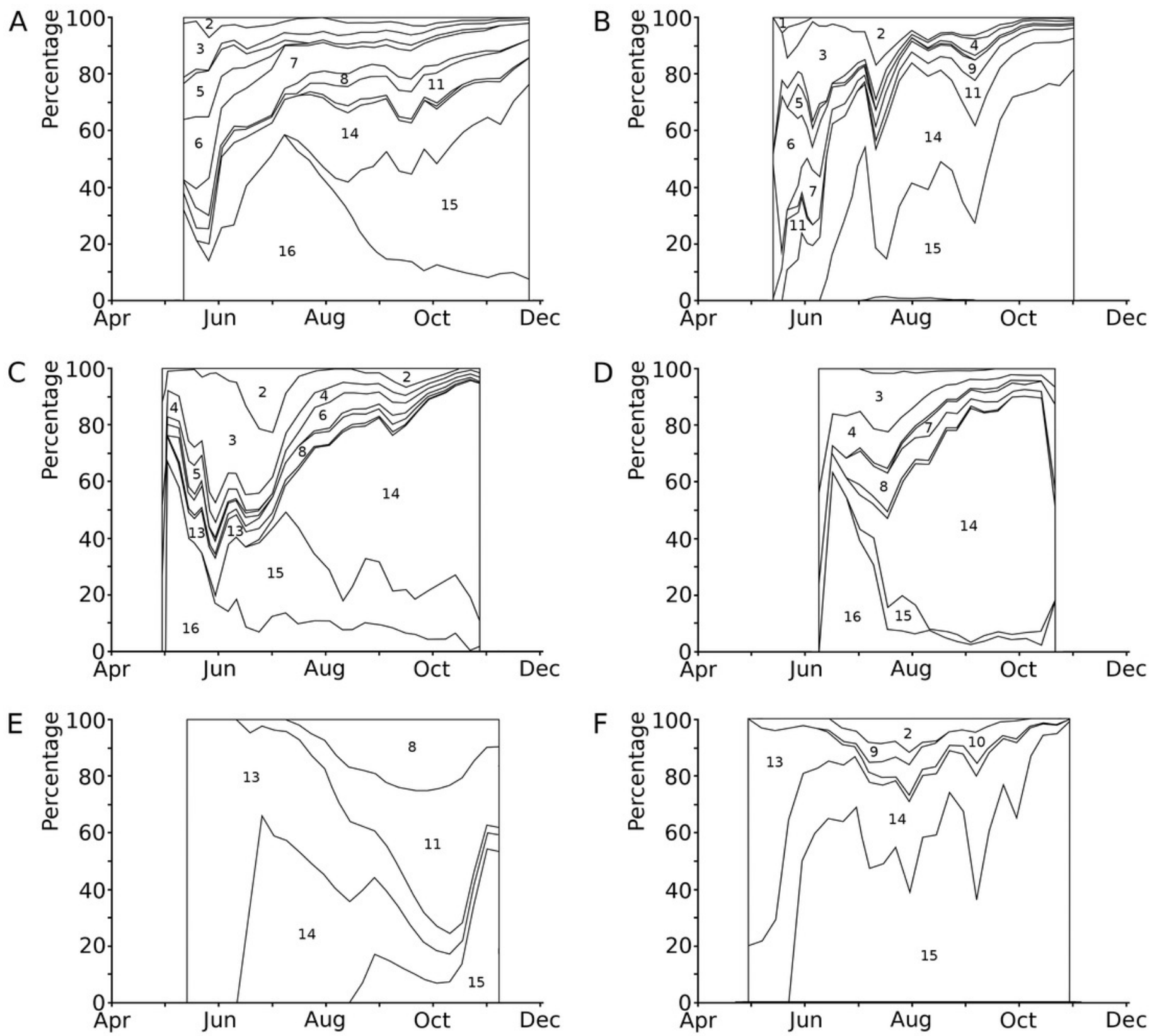


\section{Figure 4}

Senescence and microbial decay.

Sequence of colour changes from green living tissue (dark grey areas) to senescent tissue (light grey areas) and areas of microbial decay (black areas) on Nymphaea candida, photographed with translucent light.
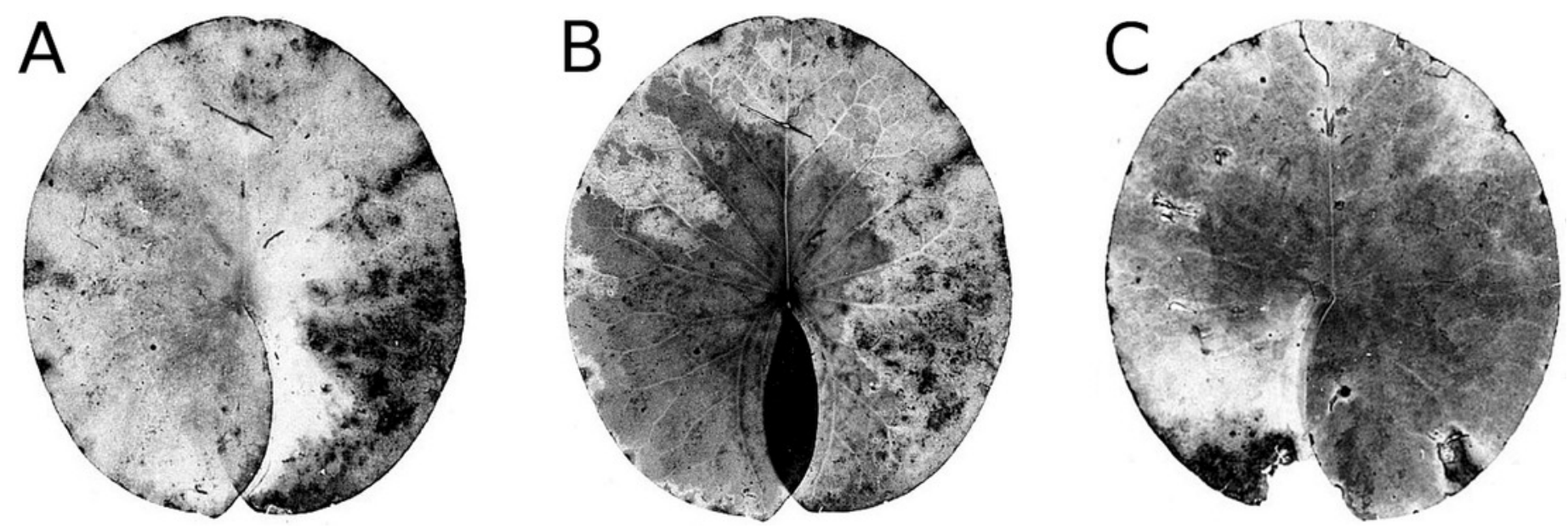


\section{Figure 5}

Frost.

Symptoms of frost damage of a whole Nuphar lutea leaf (A) and the tip of a Nuphar lutea leaf sticking out of the water which could be damaged by frost (B).

*Note: Auto Gamma Correction was used for the image. This only affects the reviewing manuscript. See original source image if needed for review.
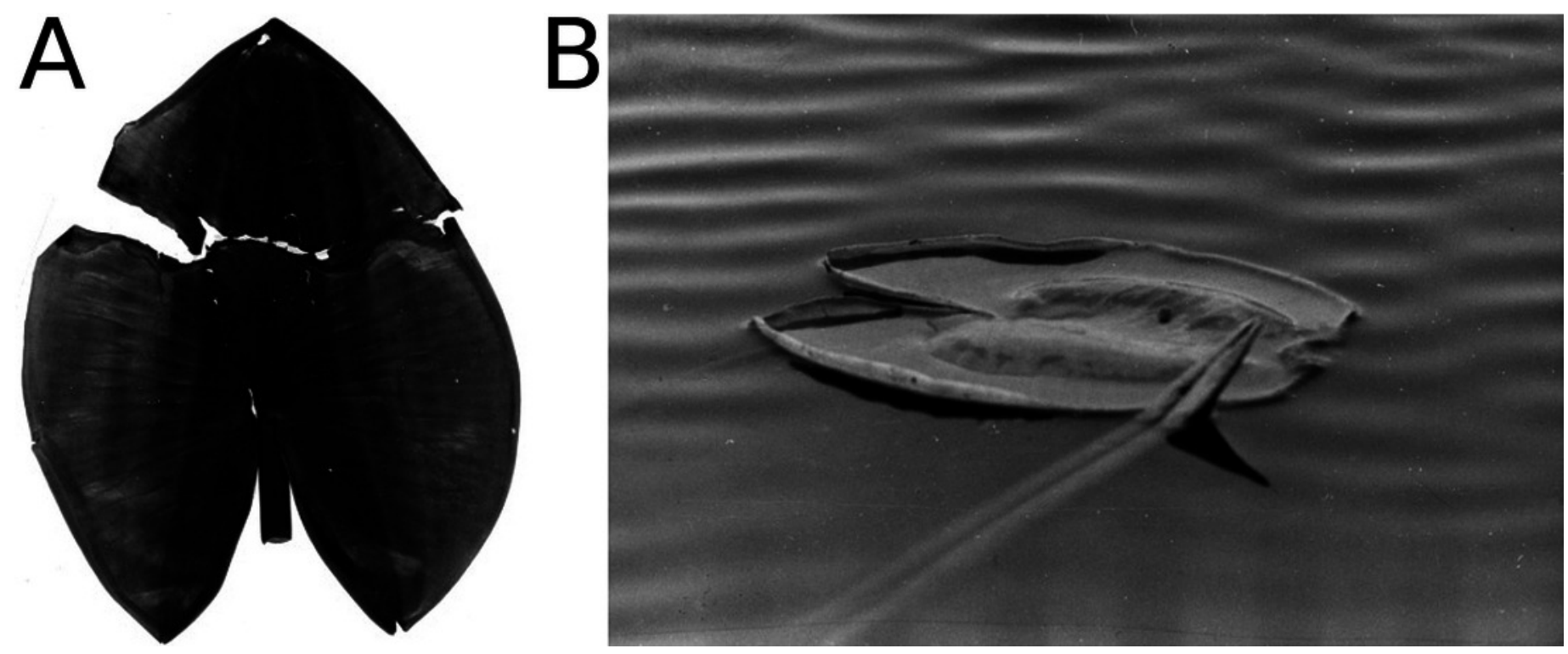


\section{Figure 6}

Hailstones.

Symptoms of damage by hailstones (white arrows) and snails (black arrows) on Nymphaea alba.
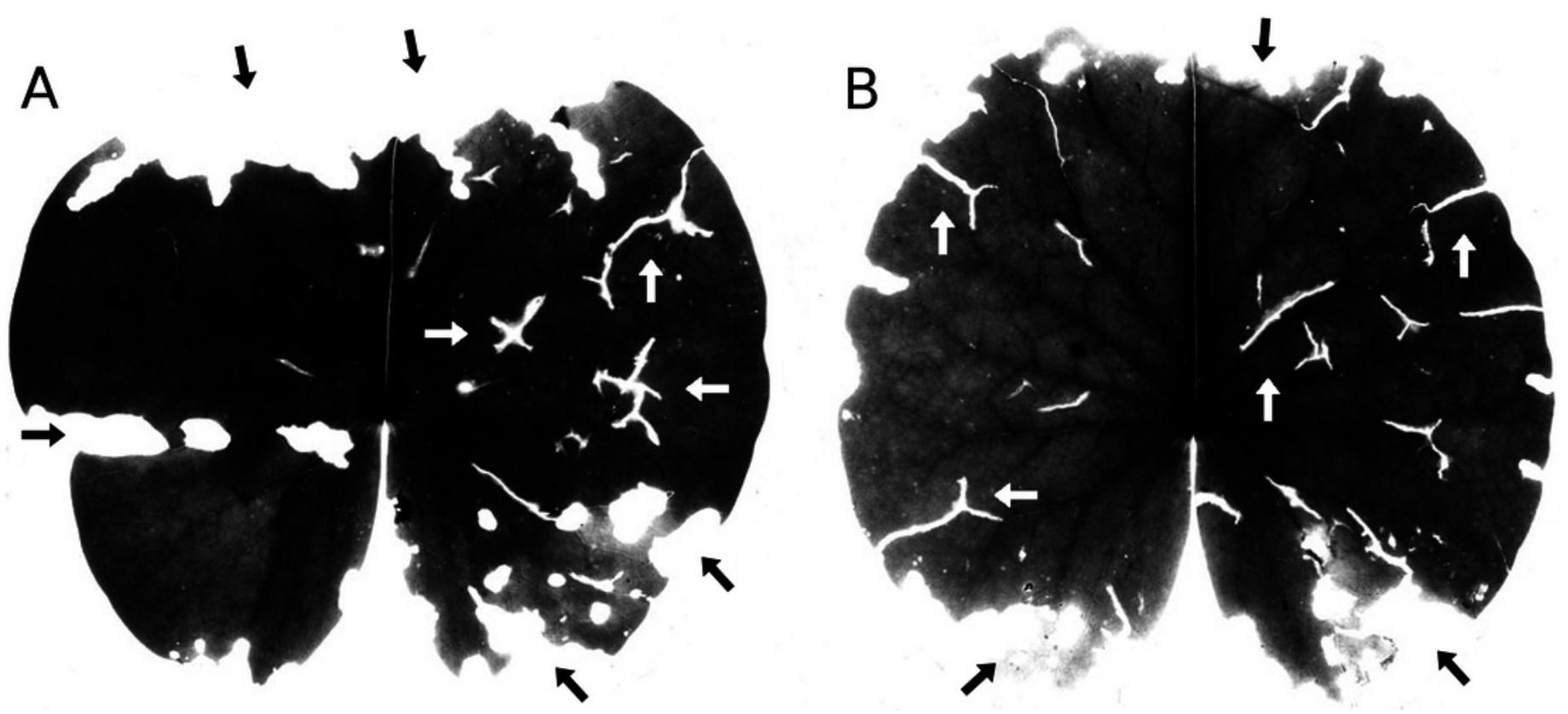
Figure 7

Wind and wave action.

Uplifted leaves as a result of wind and wave action (A, B), leading to mechanical damage as well as to dehydration by air and sun exposure, as shown at the leaf margin of Nuphar lutea (C).
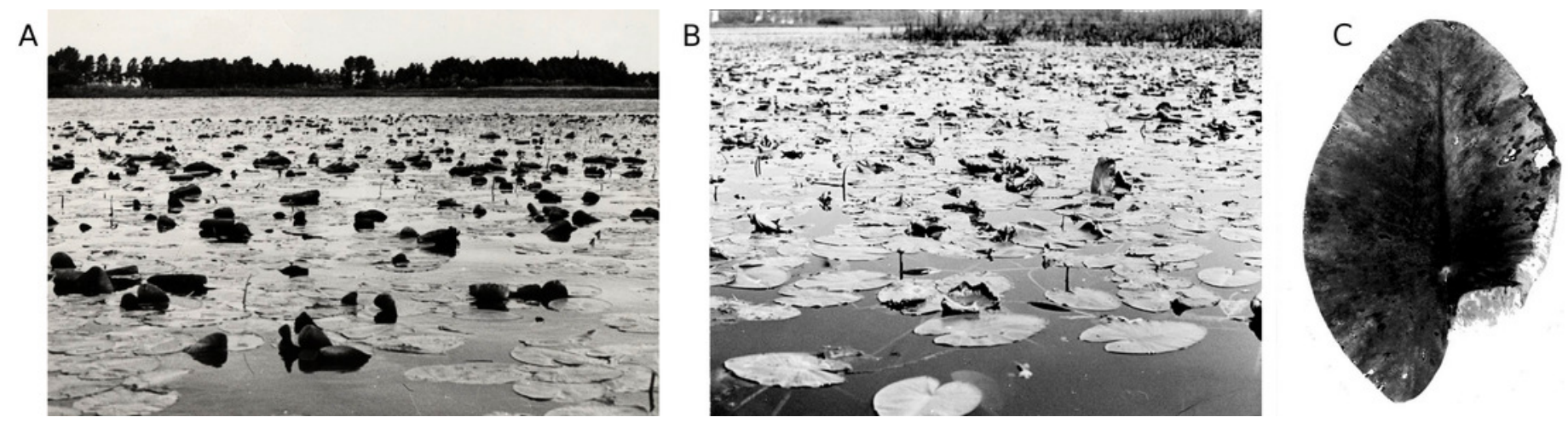


\title{
Figure 8
}

\author{
Bird scratches.
}

Bird scratches caused by the claws of Fulica atra or Gallinula chloropus, damage caused by Pythium "type $F^{\prime \prime}$, and dehydration of the leaf margin.

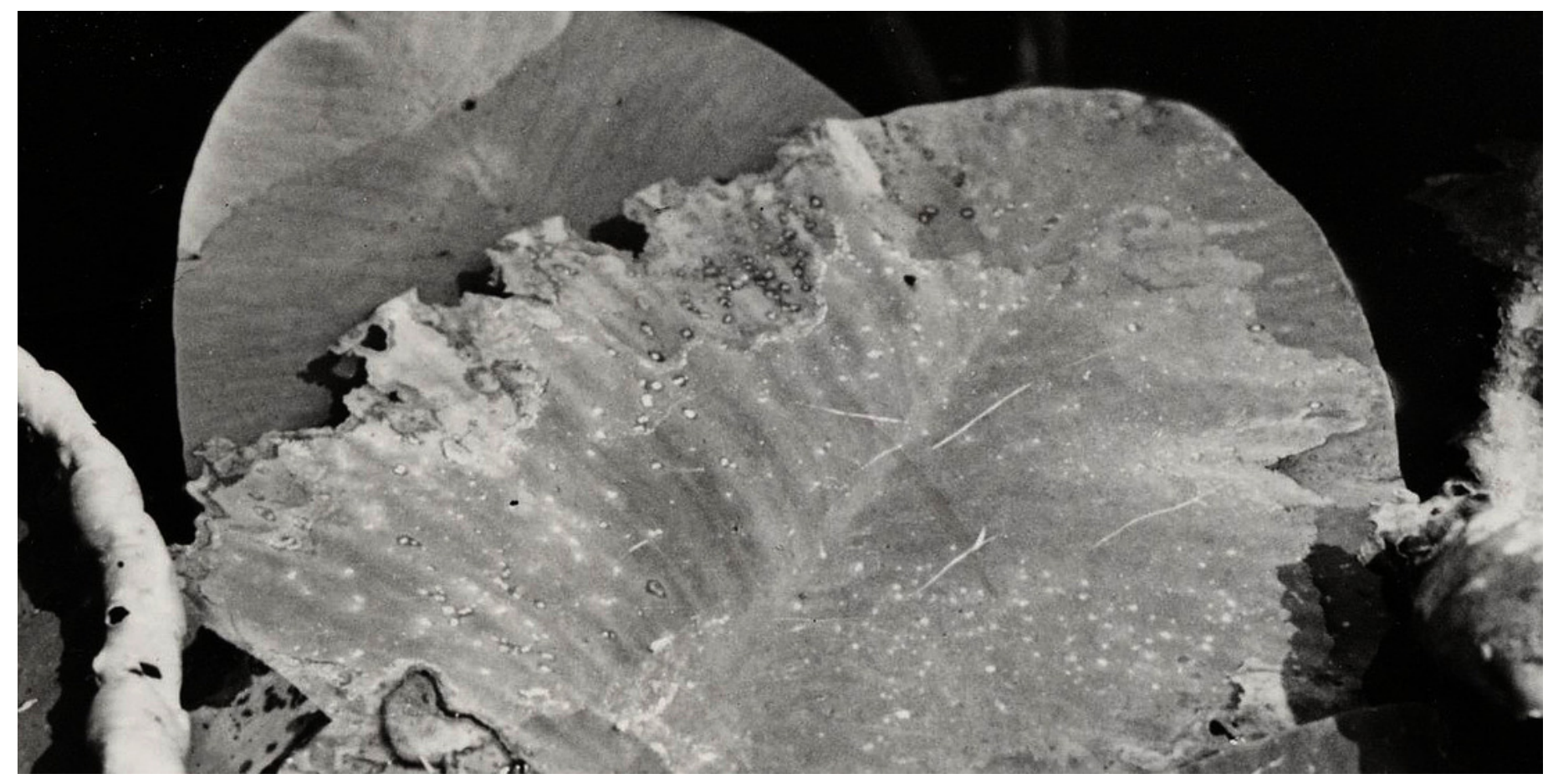


Figure 9

Consumption by coots.

Damage and leaf area loss due to the consumption of tissue by Fulica atra on Nymphaea alba.
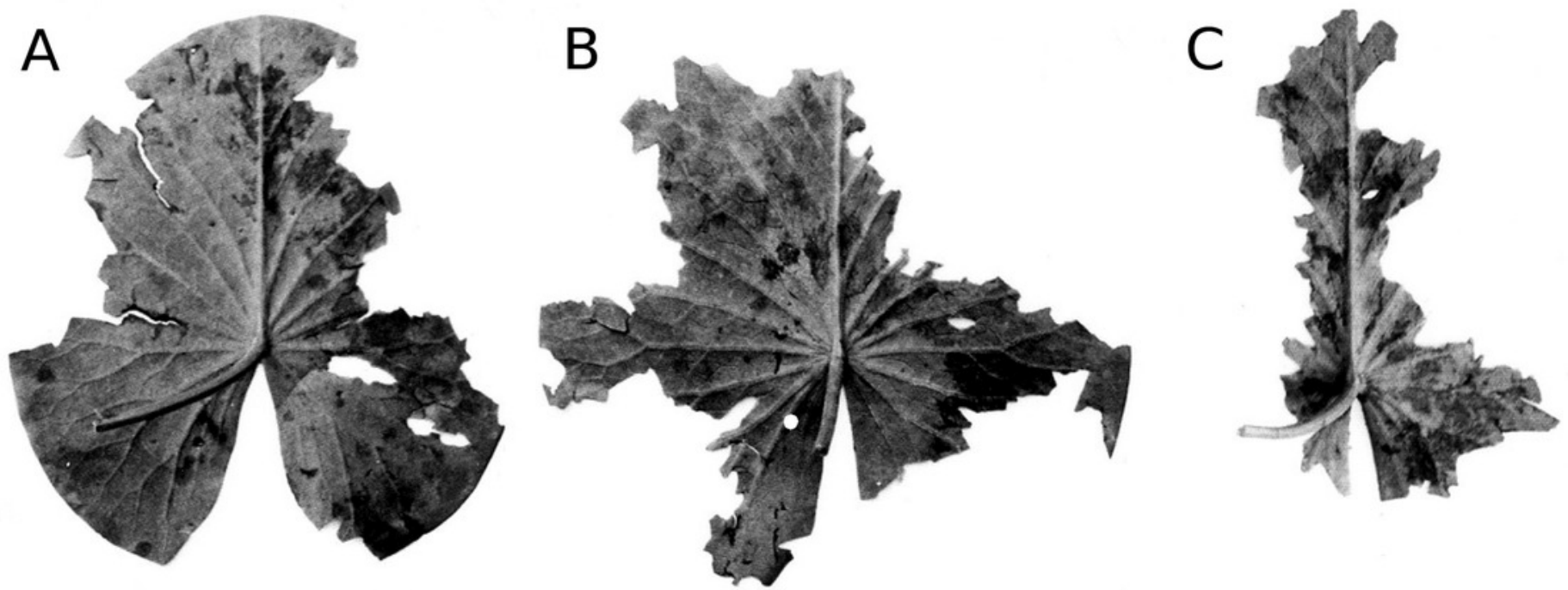


\section{Figure 10}

Consumption by pond snails

The pond snail Lymnaea stagnalis (A) causing leaf damage of Nymphaea alba, which is visible as rows of holes caused by the snail before leaf blades unroll $(B, C)$.

A
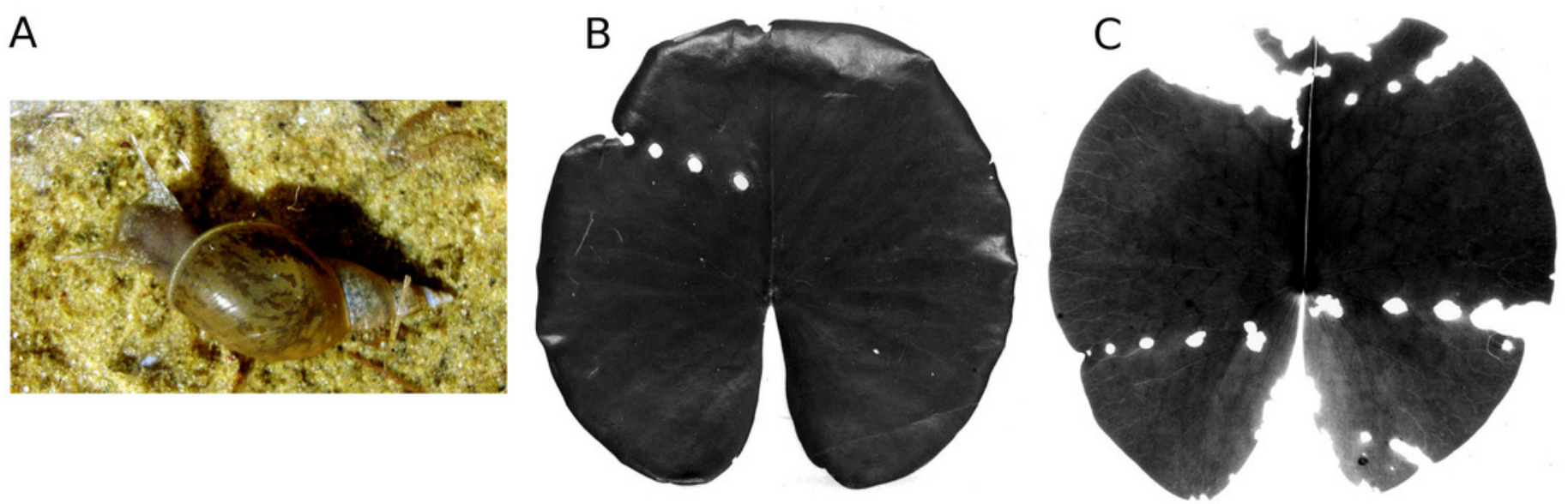


\section{Figure 11}

Consumption by the water-lily reed beetle Donacia crassipes.

Floating-leaf consumption by the water-lily reed beetle Donacia crassipes. (A) Size of consumed spots and of egg deposition holes made by imagines of the beetle on leaves of Nuphar lutea, (B) eggs deposited at the underside of a Nuphar lutea leaf, (C) imago on Nymphaea alba, (D, E, F, G) leaves of Nuphar lutea damaged as a result of consumption by $D$. crassipes. 

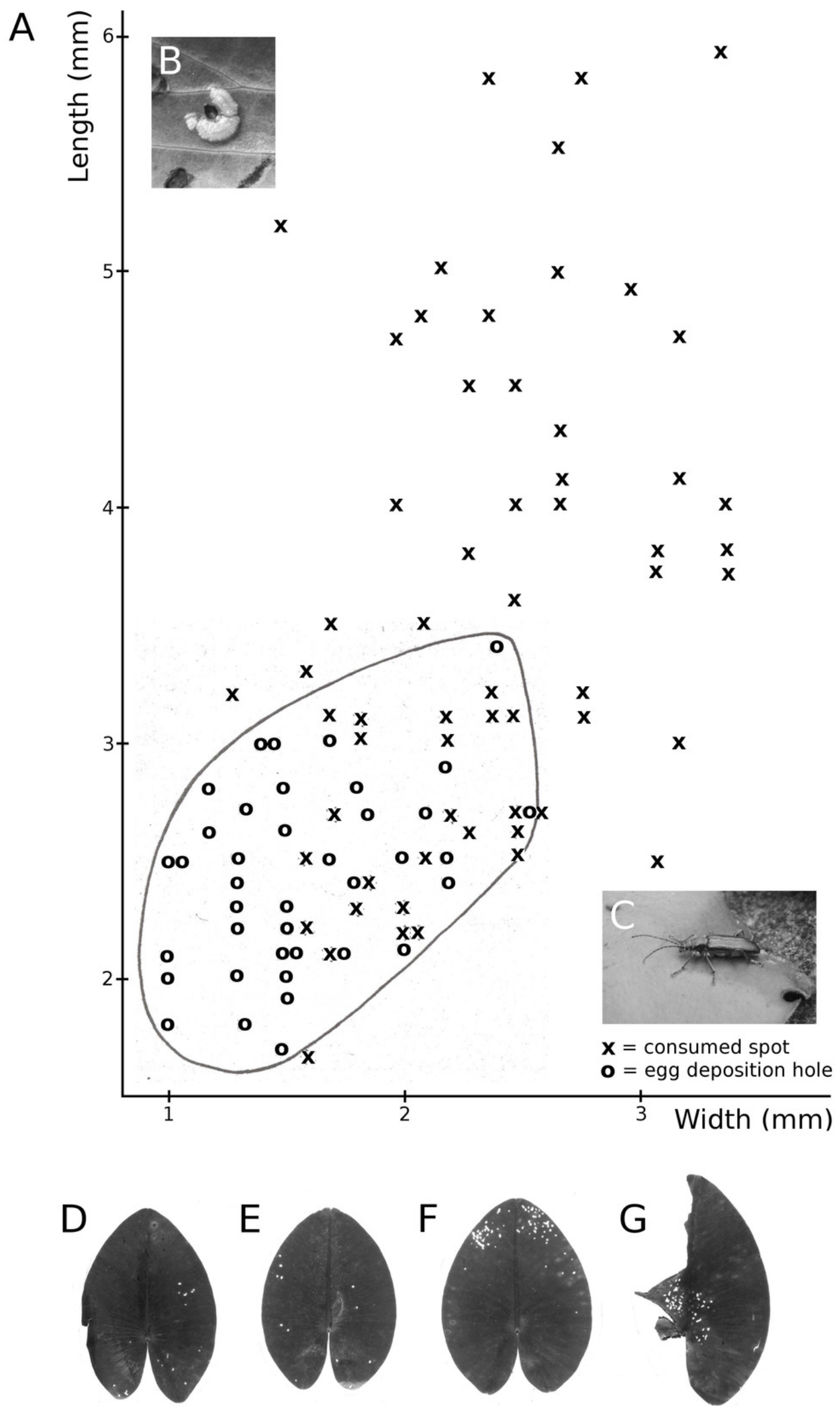


\section{Figure 12}

Consumption by the water-lily leaf beetle Galerucella nymphaeae.

Consumption of floating leaves by the water-lily leaf beetle Galerucella nymphaeae. (A) Eggs, (B) larvae and pupae, (C) imago with consumption spots, (D) typical damage patterns caused by larvae on Nymphaea alba, and $(E, F)$ damage patterns caused by larvae and imagines on Nuphar lutea.
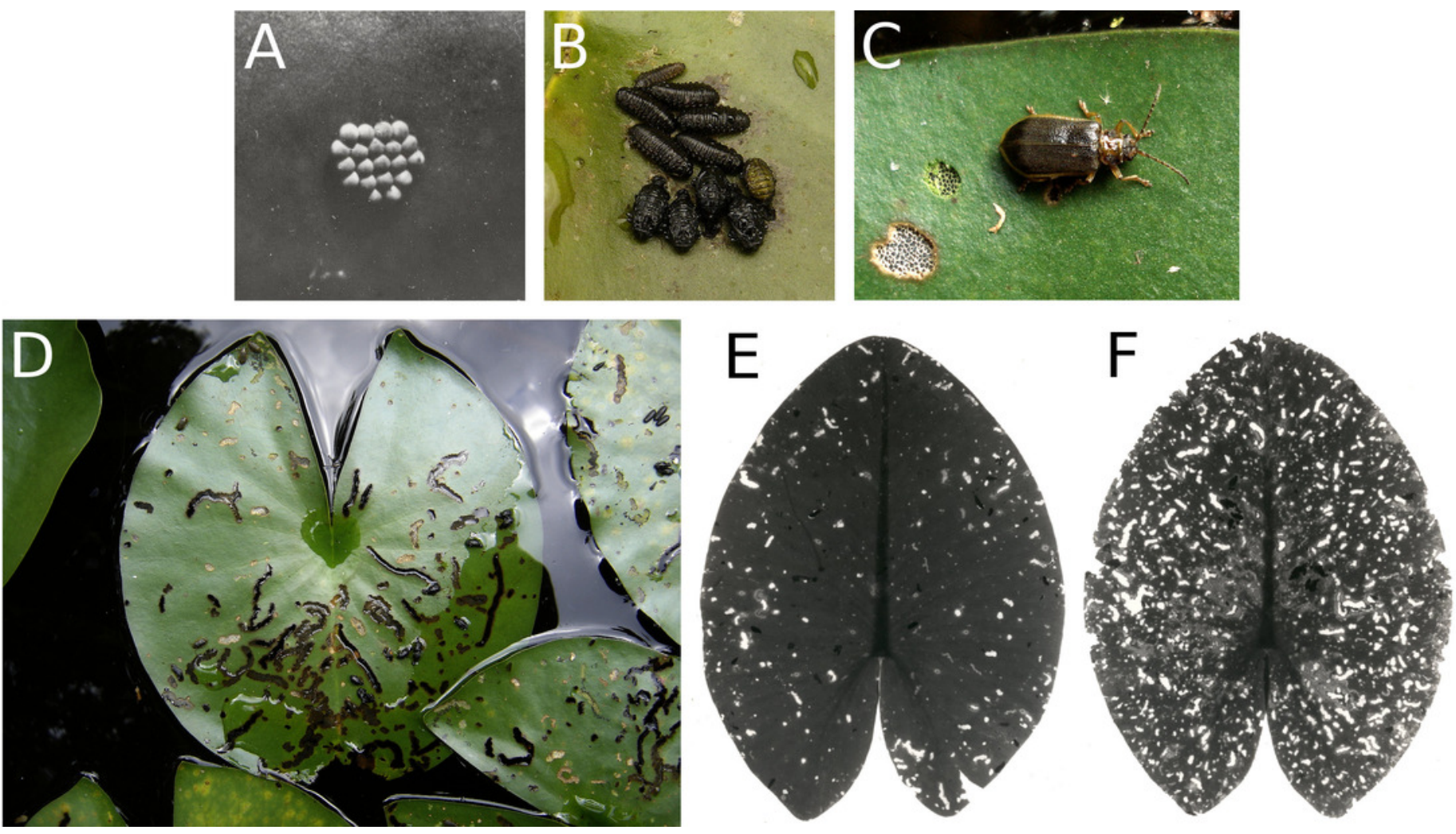


\section{Figure 13}

Consumption by the weevil Bagous rotundicollis.

Consumption by the weevil Bagous rotundicollis. (A, B) imago and (C) damaged spots indicated by white arrows along the margin on the underside of a leaf.
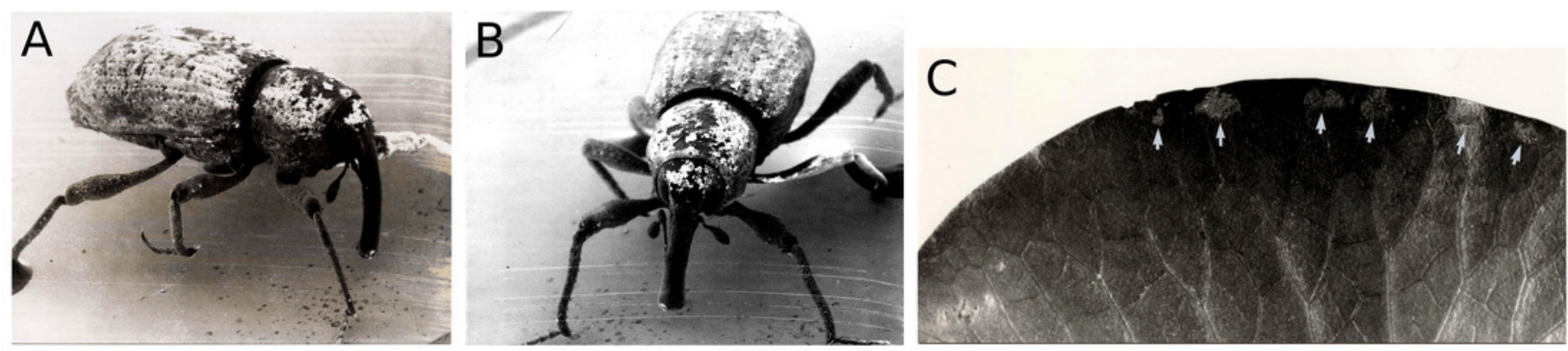


\section{Figure 14}

Consumption and damage by the brown china mark Elophila nymphaeata.

Consumption and damage by caterpillars of the brown china mark Elophila nymphaeata on Nymphaea alba. (A, B) Caterpillar in a free-floating shelter composed of two pieces of floating leaf, (C) adult moth on a leaf, (D, E) damage on floating leaves of Nymphaea alba.
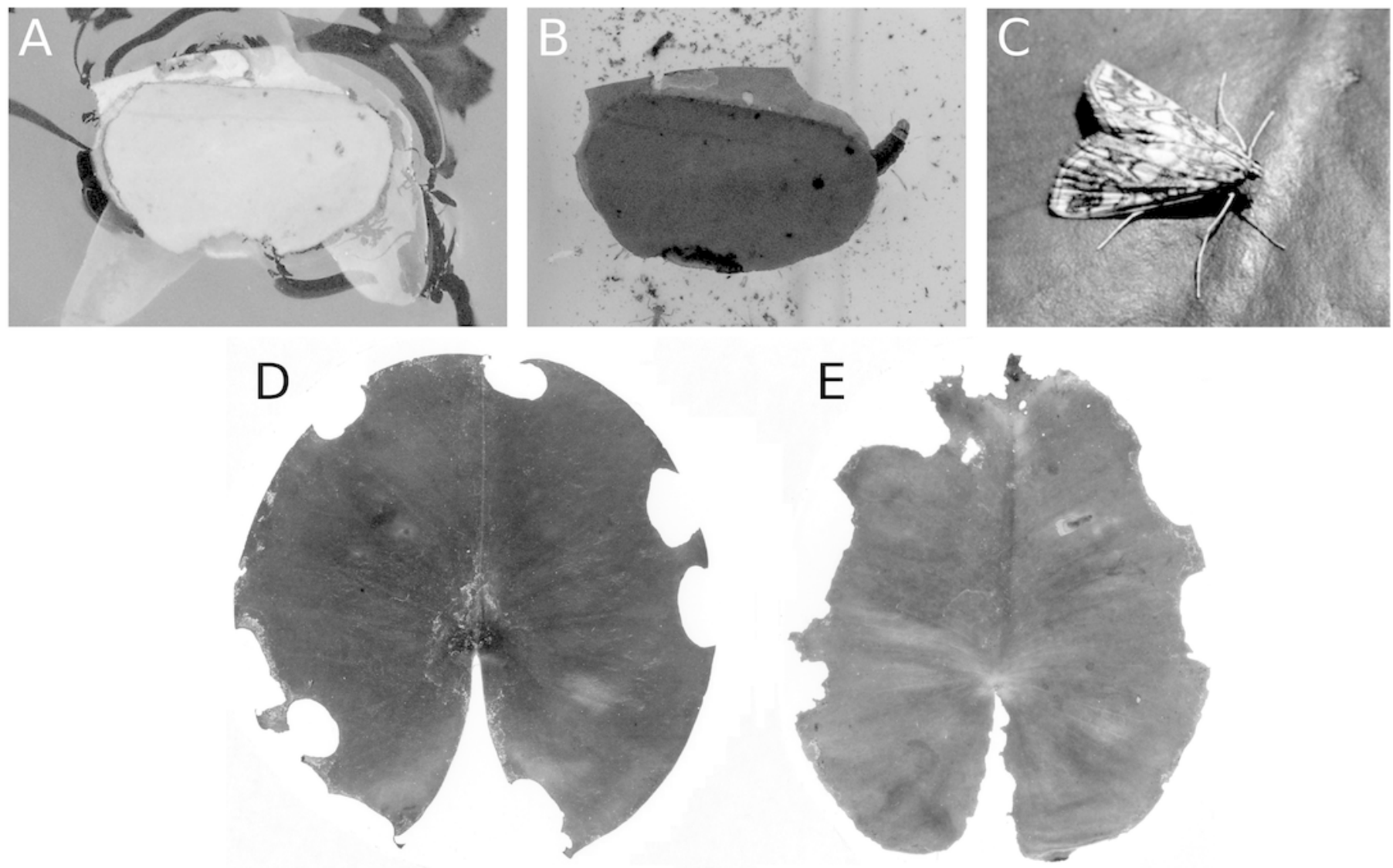


\section{Figure 15}

Mining by larvae of the dung fly Hydromyza livens.

Mining by larvae of the dung fly Hydromyza livens. (A) Eggs of Hydromyza livens on the underside of a Nuphar lutea leaf, (B) scanning electron micrograph of the head of a larva, (C) drawing of an imago, (D, E) larval mine tracks on Nuphar lutea and infection by Pythium spec. (scattered small spots). Photos of leaves taken with translucent light.

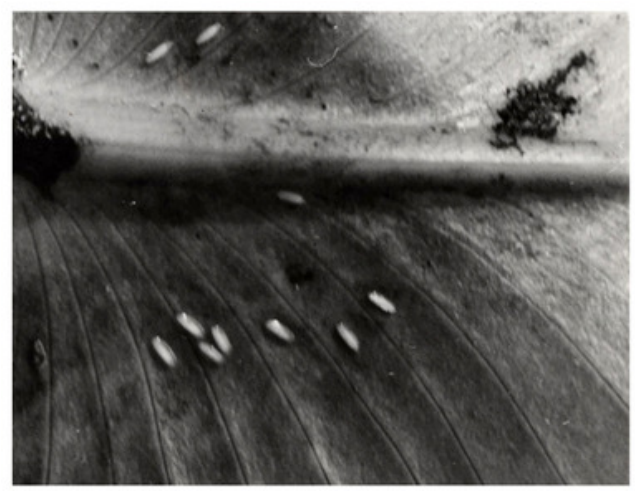

A

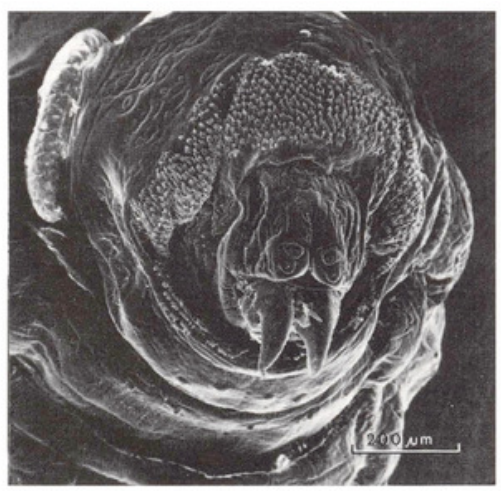

B

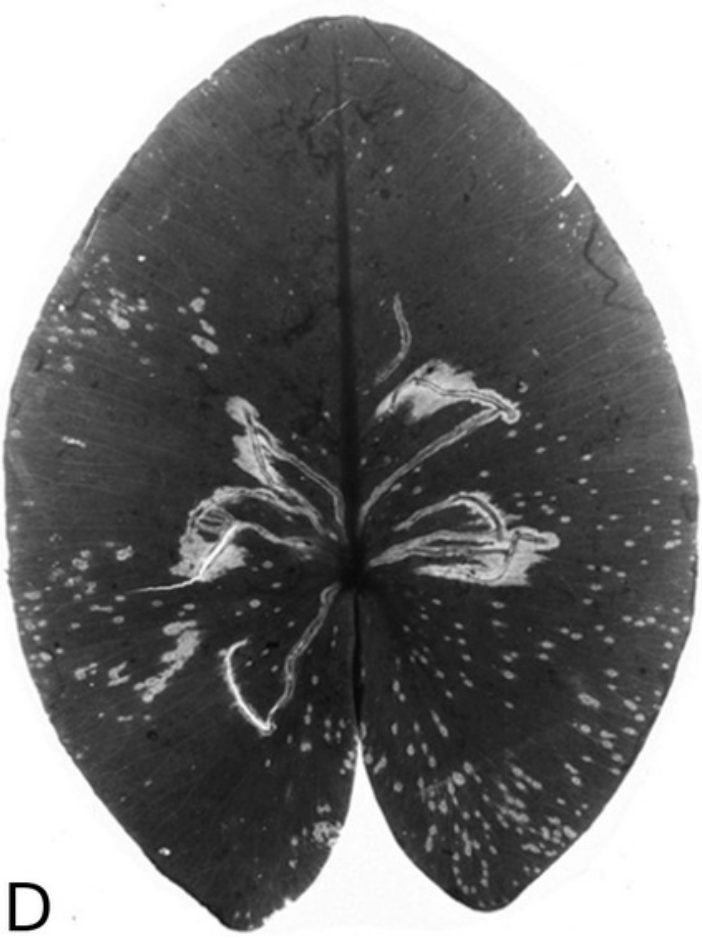

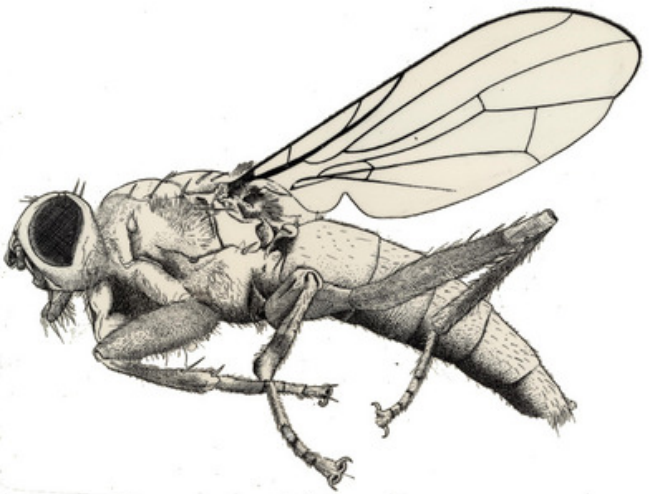

C

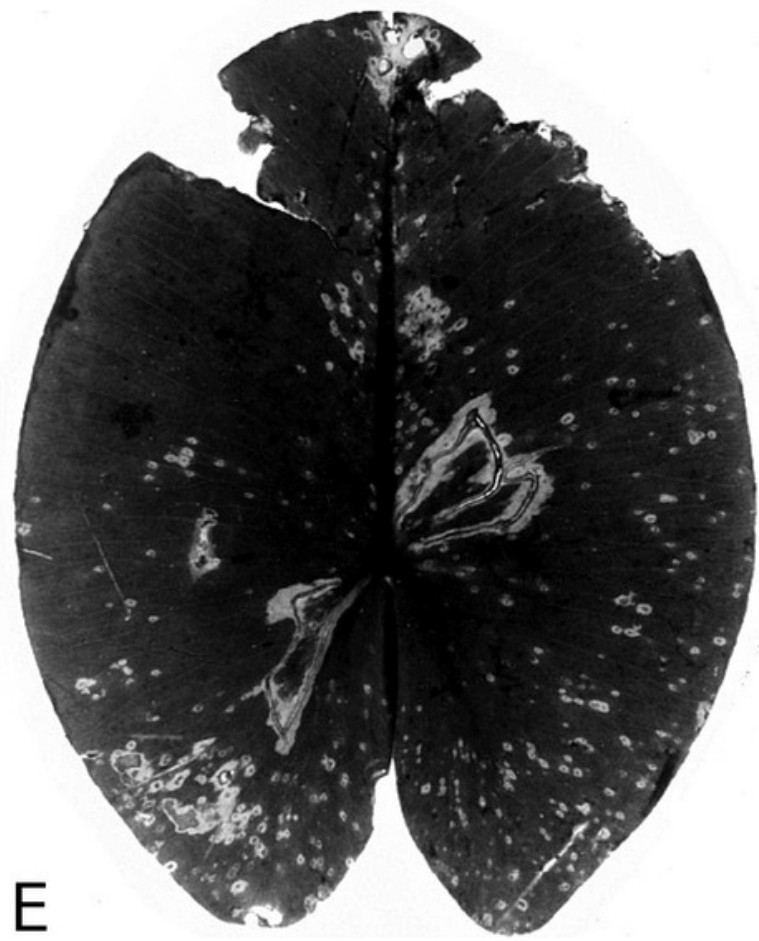




\section{Figure 16}

Mining by larvae of the chironomid Tribelos intextus.

Mining by larvae of the chironomid Tribelos intextus on Nuphar lutea.
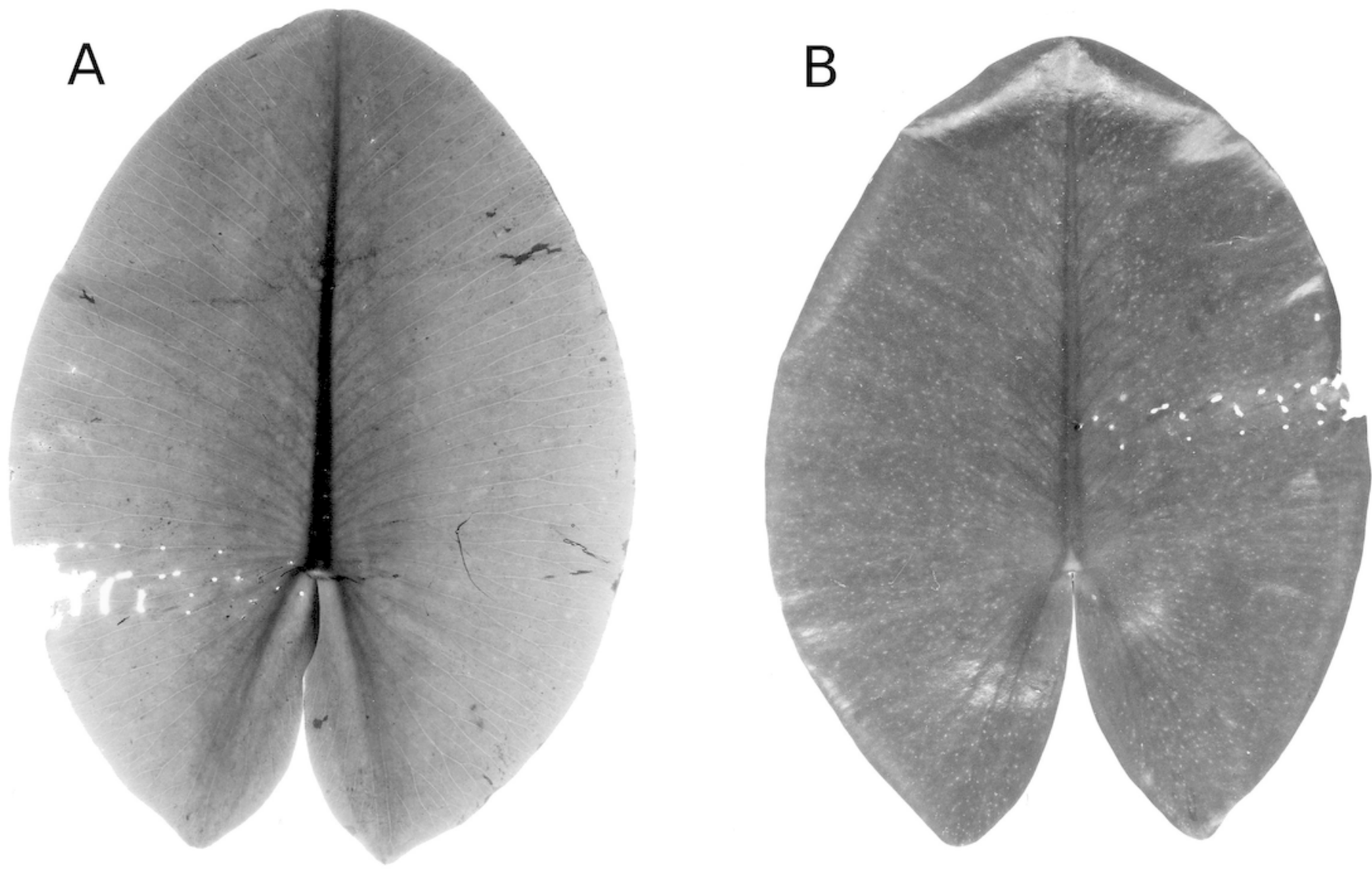
Figure 17

Typical mining patterns by larvae of Cricotopus trifasciatus .

Typical mining patterns caused by larvae of Cricotopus trifasciatus (Chironomidae) on floating leaves. Patterns in the centre of a leaf blade $(A)$ and near the leaf margin $(B, C)$.

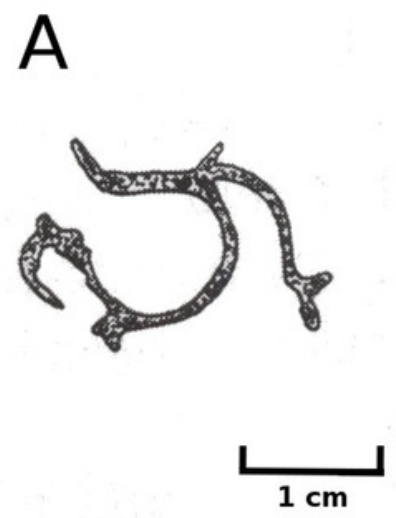

B

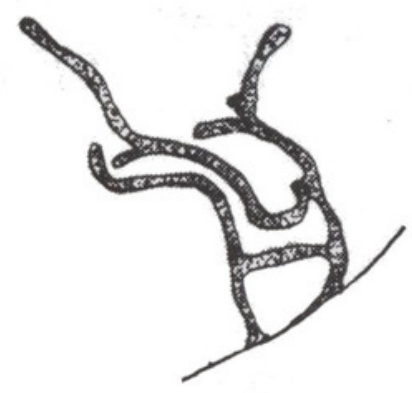

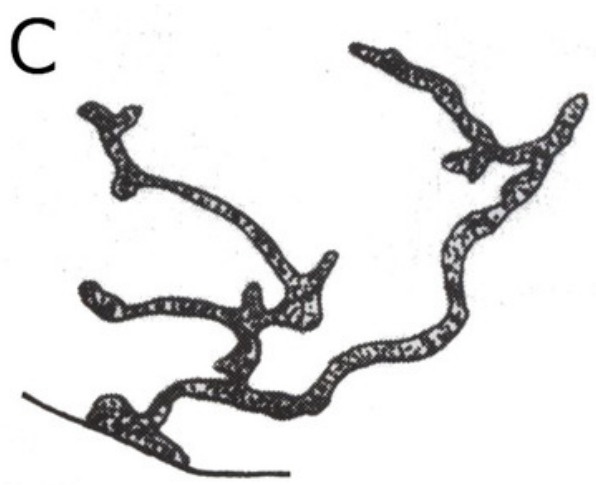




\section{Figure 18}

Typical mining patterns by larvae of Endochironomus spec.

Typical mining patterns by larvae of Endochironomus spec. (Chironomidae). Patterns on a leaf (A, B) and near the leaf margin $(C)$.

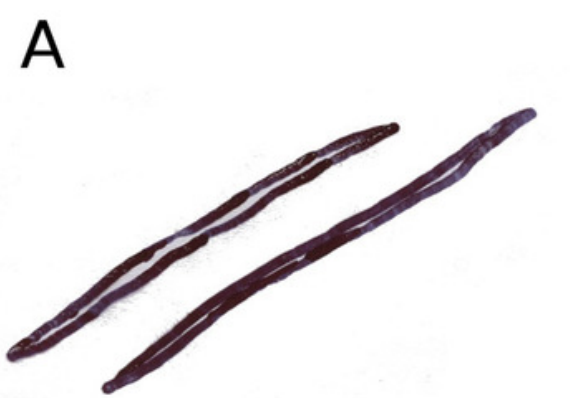

B
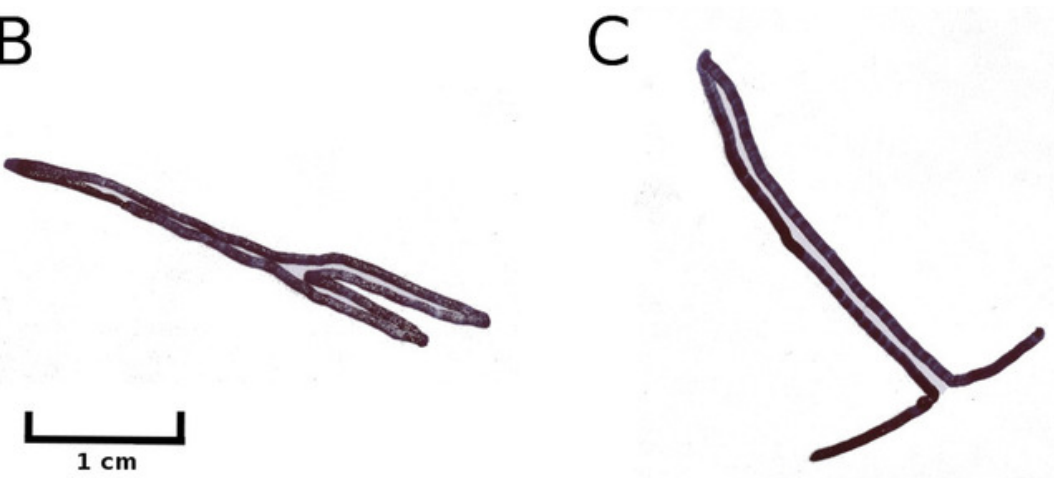


\section{Figure 19}

Damage by Pythium "type F" .

Damage by Pythium "type F" on Nuphar lutea (A-H), photographed with translucent light.
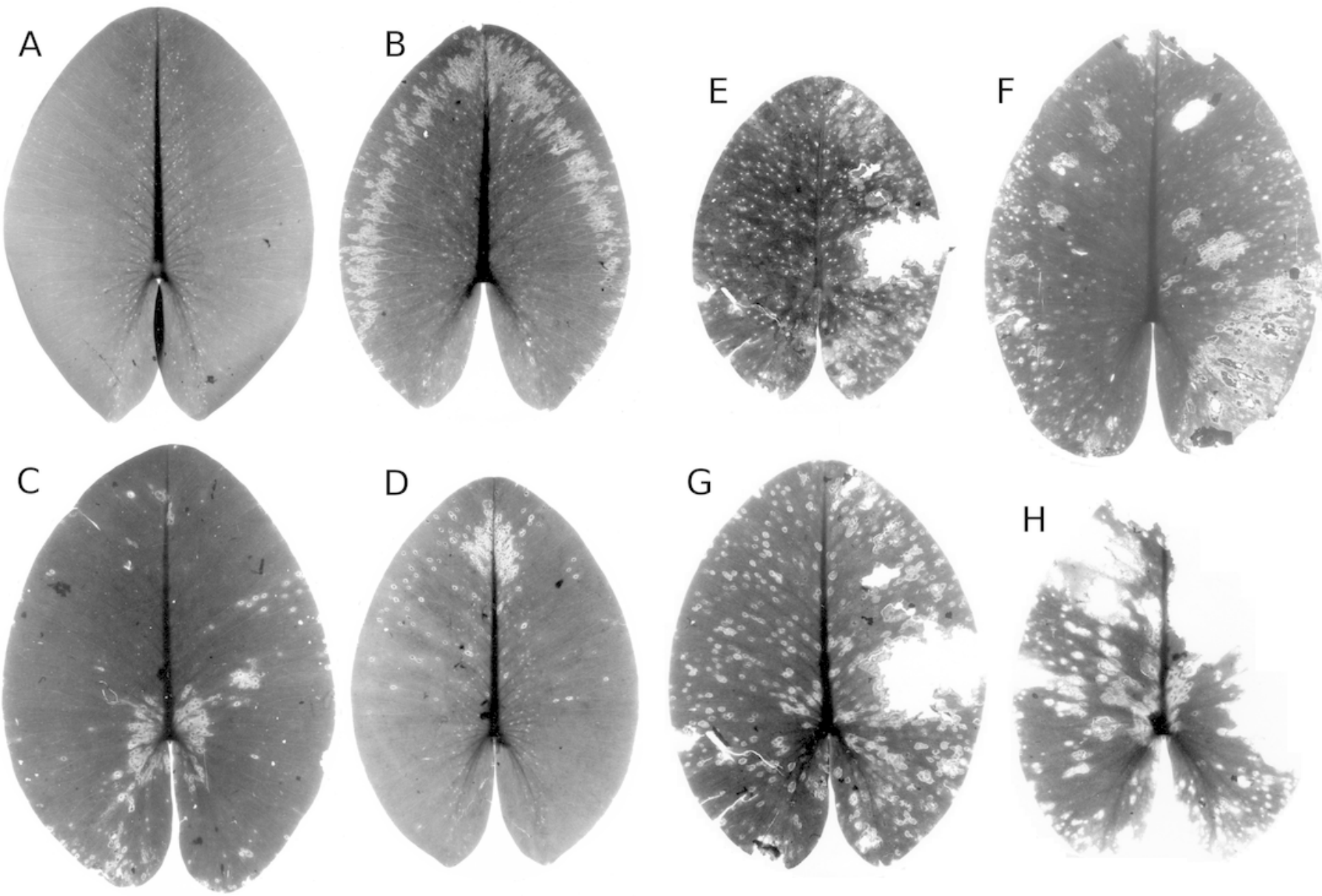


\section{Figure 20}

Damage by Colletotrichum nymphaeae.

Damage caused by Colletotrichum nymphaeae on Nymphaea alba (A, B, C, D) and infected spots consumed by snails $(A)$.
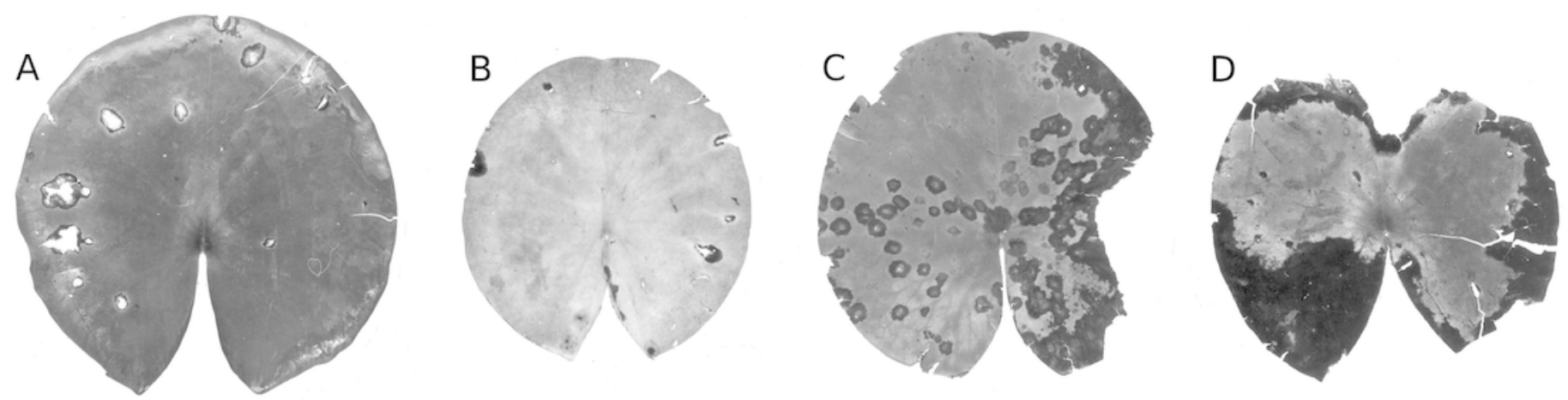


\section{Table $\mathbf{1}$ (on next page)}

Characteristics of the three study sites.

Characteristics of the three study sites in The Netherlands to investigate the initial decomposition of floating leaf blades of waterlilies 


\begin{tabular}{|l|l|l|l|}
\hline Characteristic & Haarsteegse Wiel $(\mathrm{HW})$ & Oude Waal $(\mathrm{OW})$ & Voorste Goorven (VG) \\
\hline Type of water body & Breakthrough lake & $\begin{array}{l}\text { Oxbow lake with three } \\
\text { breakthrough ponds }\end{array}$ & Moorland pond \\
\hline Location & $51^{0} 43^{\prime} 05^{\prime \prime} \mathrm{N}, 5^{0} 11^{\prime} 07^{\prime \prime} \mathrm{E}$ & $51^{0} 51^{\prime} 13^{\prime \prime} \mathrm{N}, 5^{0} 53^{\prime} 35^{\prime \prime} \mathrm{E}$ & $51^{0} 33^{\prime} 53^{\prime \prime} \mathrm{N}, 5^{0} 12^{\prime} 26^{\prime \prime} \mathrm{E}$ \\
\hline Area (ha) & 18 & 25 & 5 \\
\hline Maximum depth & $17 \mathrm{~m}$ & $1.5 \mathrm{~m}$ and 6-7 $\mathrm{m}$ & $2 \mathrm{~m}$ \\
\hline Water level fluctuations & Low & High in winter and spring & Low \\
\hline Stratification & $\begin{array}{l}\text { In summer, thermocline at } \\
4-6 \mathrm{~m}\end{array}$ & No & No \\
\hline Hydrology & $\begin{array}{l}\text { Precipitation, evaporation, } \\
\text { groundwater seepage }\end{array}$ & $\begin{array}{l}\text { Precipitation, evaporation, } \\
\text { groundwater seepage, river } \\
\text { overflow }\end{array}$ & $\begin{array}{l}\text { Precipitation, evaporation, } \\
\text { groundwater seepage }\end{array}$ \\
\hline Surrounding vegetation & Trees, shrubs, reeds & Grassland & Forest \\
\hline Wind and wave action & Low & Moderate & Moderate \\
\hline Bottom & Sand, organic $($ sapropel $)$ & Sand, clay, organic $($ sapropel) & Sand, organic (sapropel) \\
\hline Trophic state & Eutrophic & Highly eutrophic & Oligotrophic \\
\hline Alkalinity (mmol L $)^{-1} *$ & 1.5 & $4.3-6.7$ & $<0.01-0.07$ \\
\hline pH* & $7.1-8.5$ & $6.7-8.3$ & $4.7-5.5$ \\
\hline Sampling year & 1977 & 1977 & 1988 \\
\hline $\begin{array}{l}\text { Macrophyte species } \\
\text { (water depth of plot) }\end{array}$ & $\begin{array}{l}\text { Nuphar lutea },(1.5 \mathrm{~m}) \\
\text { Nymphaea candida }(2.5 \mathrm{~m})\end{array}$ & $\begin{array}{l}\text { Nuphar lutea }(1.5 \mathrm{~m}) \\
\text { Nymphaea alba }(1.5 \mathrm{~m})\end{array}$ & $\begin{array}{l}\text { Nuphar lutea }(2 \mathrm{~m}) \\
\text { Nymphaea alba }(2 \mathrm{~m})\end{array}$ \\
\hline
\end{tabular}

4 *From Brock, Boon \& Paffen (1985) and Kok, van der Velde \& Landsbergen (1990).

5 


\section{Table 2 (on next page)}

Length-area regression equations for the leaves of the three study species.

Length-area regression equations of undamaged fresh green leaves of the three study species. $\mathrm{N}=$ number of leaves used to determine the equation coefficients, $A=$ leaf area, $L=$ leaf length. 
1

\begin{tabular}{|l|l|l|l|l|}
\hline Species & $\mathrm{N}$ & Regression equation & $\mathrm{r}^{2}$ & $\mathrm{p}$ \\
\hline Nuphar lutea & 37 & $\mathrm{~A}=0.623 \mathrm{~L}^{2}$ & 0.99 & $<0.001$ \\
Nymphaea alba & 84 & $\mathrm{~A}=0.788 \mathrm{~L}^{2}$ & 0.98 & $<0.001$ \\
Nymphaea candida & 10 & $\mathrm{~A}=0.695 \mathrm{~L}^{2}$ & 0.99 & $<0.001$ \\
\hline
\end{tabular}




\section{Table 3 (on next page)}

Summary characteristics of waterlily stands.

Summary characteristics of waterlily stands in three water bodies of The Netherlands. HW = Haarsteegse Wiel, OW $=$ Oude Waal, VG = Voorste Goorven. 


\begin{tabular}{|c|c|c|c|c|c|c|c|c|}
\hline \multirow[t]{2}{*}{ Site } & \multirow[t]{2}{*}{ Species } & \multirow[t]{2}{*}{ Year } & \multicolumn{2}{|c|}{ Vegetation period } & \multicolumn{2}{|c|}{ Growth period } & \multirow{2}{*}{$\begin{array}{l}\text { Total number } \\
\text { of leaves }\left(\mathrm{m}^{-2}\right)\end{array}$} & \multirow{2}{*}{$\begin{array}{l}\text { Total potential } \\
\text { leaf area }\left(\mathrm{cm}^{2}\right)\end{array}$} \\
\hline & & & Time span & Days & Time span & Days & & \\
\hline $\mathrm{HW}$ & Nuphar lutea & 1977 & May $10-$ Nov 24 & 199 & May $10-$ Sep 13 & 127 & 77 & 49674 \\
\hline $\mathrm{OW}$ & Nuphar lutea & 1977 & May $11-$ Nov 1 & 175 & May $11-\operatorname{Sep} 7$ & 120 & 59 & 39898 \\
\hline $\mathrm{VG}$ & Nuphar lutea & 1988 & Apr $28-$ Oct 27 & 183 & Apr $28-\operatorname{Sep} 8$ & 134 & 22 & 8440 \\
\hline $\mathrm{HW}$ & Nymphaea candida & 1977 & Jun $7-$ Oct 19 & 135 & Jun $7-$ Aug 16 & 71 & 43 & 11185 \\
\hline $\mathrm{OW}$ & Nymphaea alba & 1977 & May $11-$ Nov 6 & 180 & May $11-\operatorname{Sep} 7$ & 120 & 108 & 53035 \\
\hline $\mathrm{VG}$ & Nymphaea alba & 1988 & Apr $28-$ Oct 27 & 183 & Apr $28-\operatorname{Sep} 8$ & 134 & 80 & 23053 \\
\hline
\end{tabular}

3 


\section{Table 4(on next page)}

Damage to leaves during initial decomposition.

Prevalence of different causes of leaf damage during initial decomposition of floating leaves at six plots in three water bodies located in The Netherlands. The total number of leaves and the total potential area of leaves per plot are listed in Table 3. av. = average, max. = maximum.

(1) = Nuphar lutea, Haarsteegse Wiel, 1977; (2) = Nuphar lutea, Oude Waal, 1977; (3) = Nuphar lutea, Voorste Goorven, 1988; (4) = Nymphaea candida, Haarsteegse Wiel, 1977; (5) = Nymphaea alba, Oude Waal, 1977; (6) = Nymphaea alba, Voorste Goorven, 1988. 


\begin{tabular}{|c|c|c|c|c|c|c|c|c|c|c|c|c|c|c|c|c|c|c|c|c|c|c|c|c|}
\hline \multirow[t]{3}{*}{ Cause of damage } & \multicolumn{6}{|c|}{ Percentage of leaves affected } & \multicolumn{12}{|c|}{ Percentage of potential area affected } & \multicolumn{6}{|c|}{ Photosynthetic area lost $\left(\mathrm{cm}^{2}\right)$} \\
\hline & \multirow[t]{2}{*}{ (1) } & \multirow[t]{2}{*}{$(2)$} & \multirow[t]{2}{*}{ (3) } & \multirow[t]{2}{*}{ (4) } & \multirow[t]{2}{*}{ (5) } & \multirow[t]{2}{*}{ (6) } & \multicolumn{2}{|c|}{ (1) } & \multicolumn{2}{|c|}{$(2)$} & \multicolumn{2}{|c|}{ (3) } & \multicolumn{2}{|c|}{ (4) } & \multicolumn{2}{|c|}{ (5) } & \multicolumn{2}{|c|}{ (6) } & \multirow[t]{2}{*}{$(1)$} & \multirow[t]{2}{*}{$(2)$} & \multirow[t]{2}{*}{ (3) } & \multirow[t]{2}{*}{ (4) } & \multirow[t]{2}{*}{$(5)$} & \multirow[t]{2}{*}{ (6) } \\
\hline & & & & & & & av. & max. & av. & max. & av. & max. & av. & $\max$. & av. & max. & av. & $\max$. & & & & & & \\
\hline Senescence & 79 & 92 & 91 & 84 & 78 & 64 & 6.3 & 40.0 & 6.2 & 19.0 & 4.8 & 23.5 & 10.9 & 39.0 & 5.4 & 35.0 & 2.9 & 15.7 & 4278 & 2508 & 186 & 2181 & 4727 & 2748 \\
\hline Frost & - & 2 & - & - & - & - & - & - & $<0.1$ & \begin{tabular}{|l|}
0.8 \\
\end{tabular} & - & - & - & - & - & - & - & - & - & 5 & - & - & - & - \\
\hline Hail stones & - & - & - & - & - & - & - & - & - & - & - & - & - & - & - & - & - & - & - & - & - & - & - & - \\
\hline Dehydration & 23 & 37 & - & 9 & 28 & 6 & 0.5 & 5.0 & 1.0 & 6.9 & - & - & 0.1 & 0.6 & 0.6 & 7.8 & 0.2 & 8.0 & 384 & 603 & - & 9 & 854 & 48 \\
\hline Mechanical damage & 78 & 47 & - & 74 & 80 & - & 1.1 & 8.8 & 1.2 & 10.0 & - & - & 0.8 & 3.3 & 1.5 & \begin{tabular}{|l|}
10.9 \\
\end{tabular} & - & - & 546 & 577 & - & 95 & 1118 & - \\
\hline Bird scratches & 83 & 59 & - & 84 & 77 & - & 0.7 & 1.0 & 0.5 & 1.0 & - & - & 0.6 & 1.0 & 0.6 & 1.0 & - & - & 382 & 223 & - & 83 & 386 & - \\
\hline $\begin{array}{l}\text { Consumption by } \\
\text { coots }\end{array}$ & 36 & 14 & - & 12 & 50 & - & 0.8 & 10.0 & 0.6 & 18.0 & - & - & 0.1 & 0.9 & 0.6 & 3.0 & - & - & 385 & 204 & - & 14 & 442 & - \\
\hline $\begin{array}{l}\text { Consumption by } \\
\text { pond snails }\end{array}$ & 56 & 12 & - & 12 & 13 & - & 2.5 & 10.0 & 0.4 & 5.4 & - & - & 0.3 & 5.0 & 0.3 & 8.0 & - & - & 1113 & 203 & - & 26 & 120 & - \\
\hline $\begin{array}{l}\text { Consumption by } \\
\text { reed beetles }\end{array}$ & 65 & 63 & 73 & 70 & 54 & - & 0.6 & 2.0 & 0.6 & 1.8 & 0.9 & 2.0 & 0.6 & 1.2 & 0.4 & 1.6 & - & - & 375 & 285 & 64 & 74 & 324 & - \\
\hline $\begin{array}{l}\text { Consumption by } \\
\text { waterlily beetles }\end{array}$ & - & - & - & - & - & 24 & - & - & - & - & - & - & - & - & - & - & 0.3 & 2.7 & - & - & - & - & - & 85 \\
\hline \begin{tabular}{|l|}
$\begin{array}{l}\text { Consumption by } \\
\text { weevils }\end{array}$ \\
\end{tabular} & - & - & - & - & - & 29 & - & - & - & - & - & - & - & - & - & - & 0.2 & 1.0 & - & - & - & - & - & 63 \\
\hline $\begin{array}{l}\text { Consumption and } \\
\text { damage by the } \\
\text { brown china mark }\end{array}$ & 10 & 3 & - & - & 6 & - & 0.4 & \begin{tabular}{|l|} 
\\
\end{tabular} & \begin{tabular}{|l|} 
\\
\end{tabular} & 3.6 & - & - & - & - & 0.1 & 3.9 & - & - & $\mid 144$ & 43 & - & - & 66 & - \\
\hline $\begin{array}{l}\text { Mining by a dung } \\
\text { fly }\end{array}$ & 65 & 69 & 73 & - & - & - & 1.3 & 6.5 & 1.1 & \begin{tabular}{|l|}
4.0 \\
\end{tabular} & 1.3 & 3.5 & - & - & - & - & - & - & 786 & 516 & \begin{tabular}{|l|}
119 \\
\end{tabular} & - & - & - \\
\hline \begin{tabular}{|l} 
Mining by \\
chironomids
\end{tabular} & 14 & 2 & - & 2 & 6 & - & 0.2 & 5.0 & $<0.1$ & \begin{tabular}{|l|}
1.0 \\
\end{tabular} & - & - & $<0.1$ & \begin{tabular}{ll|}
0.4 \\
\end{tabular} & $<0.1$ & 1.0 & - & - & 99 & 7 & - & 3 & 33 & - \\
\hline \begin{tabular}{|l|} 
Mining by \\
Endochironomus
\end{tabular} & 5 & - & 50 & 12 & 25 & 23 & $<0.1$ & \begin{tabular}{|l|}
1.2 \\
\end{tabular} & - & - & 1.1 & 5.0 & 0.1 & 1.0 & 0.3 & 1.8 & 0.5 & 5.4 & 34 & - & 99 & 13 & 181 & 110 \\
\hline $\begin{array}{l}\text { Infection by } \\
\text { Pythium "type F" }\end{array}$ & 86 & 92 & 77 & - & - & - & 4.2 & 11.8 & 6.1 & $\mid 12.9$ & 1.0 & 4.9 & - & - & - & - & - & - & 2879 & 3153 & 277 & - & - & - \\
\hline $\begin{array}{l}\text { Infection by } \\
\text { Colletotrichum } \\
\text { nymphaeae }\end{array}$ & - & - & - & 79 & 53 & 94 & - & - & - & - & - & - & 6.7 & $\mid 17.9$ & 6.1 & $|21.7|$ & 2.1 & 8.8 & - & - & - & $\mid 3274$ & 11464 & 767 \\
\hline Microbial decay & 56 & 86 & 59 & 56 & 72 & 60 & 4.9 & 26.3 & 9.7 & 26.1 & 4.6 & 80.3 & 0.4 & 5.3 & 2.8 & 26.8 & 1.3 & 64.3 & 8803 & 11844 & 766 & 182 & 5634 & 6314 \\
\hline Unknown causes & 65 & 5 & - & 19 & 34 & - & 7.2 & 33.3 & 0.1 & \begin{tabular}{|l|}
1.0 \\
\end{tabular} & - & - & 1.0 & \begin{tabular}{|l|}
26.7 \\
\end{tabular} & 1.6 & \begin{tabular}{|l|}
40.0 \\
\end{tabular} & 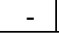 & - & 3888 & 20 & - & 115 & 1235 & 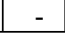 \\
\hline
\end{tabular}

